\title{
A firm-level analysis of the upstream-downstream dichotomy in the oil-stock nexus
}

\author{
Raymond Swaray* and Afees A. Salisu'
}

\begin{abstract}
In this paper, we query whether the stock prices of nonintegrated firms in the upstream and downstream sectors of the global oil supply chain respond symmetrically to changes in oil prices. This inquiry relates to the "homogenous expectation" assumption among investors and fund managers pertaining to the returns and variances of assets of specialized firms operating in upstream and downstream sectors of the supply chain. Motivated by the Arbitrage Pricing Theory, we formulate a Panel Autoregressive Distributed Lag (PARDL) model, which explains the possible macroeconomic factors in the oil-stock nexus as well as any inherent persistence and heterogeneity effects due to large cross-sections and time. In accordance with the Shin et al. (2014) approach, a Nonlinear Panel ARDL model is also formulated to test for possible asymmetric responses of the nonintegrated oil firms to positive and negative changes in the oil price. Our findings indicate that the stock prices of upstream and downstream firms move in contrasting directions in response to changes in the benchmark crude oil prices in the long-run. Specifically, we show that the stock prices of upstream sector firms increased in response to an increase in oil prices, while the reverse holds for the stock prices of downstream firms. In the short run, returns on the stock of firms in both sectors increase following an increase in oil prices; however, downstream firms' stock returns decreased in response to negative oil price shocks. The findings further show that both sectors respond differently to episodic changes in market conditions that emanated from the global financial crisis. However, upstream firms show a stronger response to changing market conditions than their downstream counterparts.
\end{abstract}

JEL Codes: C23, F41, G11, G12, Q43

Keywords: stock price, crude oil price, price transmission, portfolio management

\footnotetext{
* Economics Subject Group, University of Hull Business, University of Hull, Cottingham Road, UK. Email: r.swaray@hull.ac.uk; Phone: +44(0)1482463545.

$\dagger$ Centre for Econometric \& Allied Research, University of Ibadan, Nigeria. Email: adebare1@yahoo.com; aa.salisu@cear.org.ng; Phone: +234(0)8034711769.
} 


\section{A firm-level analysis of upstream-downstream dichotomy in the oil-stock}

nexus

\subsection{Introduction}

Despite efforts to secure energy from renewable sources over the last decade, oil and gas remain the mainspring of energy security for industrial production and household consumption in modern economies. Consequently, a plethora of literature has examined the nexus between oil price and stock prices/returns (for example Sadorsky, 2014; Salisu and Oloko, 2015; Bastianin et al., 2016; Ftiti et al., 2016; Gupta, 2016; Ding et al., 2017). These contemporary studies pursue differentiated research interests, adopt varying methodologies and return mixed findings. Beginning with the study on GCC countries, Arouri and Rault, (2010) show strong statistical evidence that the causal relationship between oil prices and stock markets is consistently bi-directional for Saudi Arabia; however, the causal relationship is unidirectional from oil price shocks to the stock price in the other GCC countries. Sadorsky, (2014) find that the emerging market stock prices and oil prices display leverage effects where oil provides the least expensive hedge for stock market prices. Much later, for the Chinese stock market, Ding et al. (2017) also show that international crude oil price fluctuations significantly influence stock market fundamentals. Theoretically, the valuation of stock is based on the discounted sum of expected future cash flows; thus, isolating such factor(s) that affect the cash-flows is of utmost relevance and importance to investors and policy makers (Arouri and Rault, 2010). In this regard, pioneering studies (for example Jones and Kaul, 1996; Huang et al., 1996; Sadorsky, 1999) establish a significant association between oil price movements and stock returns.

In particular, Sadorsky (2001) and Boyer and Filion (2007) used multi-factored models to identify oil and gas prices, exchange rate, and interest rates as significant market-risk factors encountered by Canadian oil and gas firms. A similar study on UK firms by El-Sharif et al. (2005) had conclusions similar to Sadorsky (2001). Ramos and Veiga (2011) show that the oil price has global significance to the oil industry and that stock returns of oil and gas firms respond "asymmetrically to changes in oil prices" (p.1). Further use of monthly firm-level data from 70 countries by Gupta (2016) shows that firms located in high oil producing countries or that strong encounter competition from other firms in the same industry are more sensitive to oil price shocks, while firms located in noncompetitive oil and gas industries are less sensitive to oil price shocks. 
Kang et al. (2017) show that stock returns of oil and gas companies respond negatively to U.S. macroeconomic policy uncertainty but positively to demand shocks, while stock returns of firms in upstream, midstream and downstream sectors respond heterogeneously to structural shocks. Diaz and Perez de Gracia, (2017) examine the impact of oil price shocks on stock returns of four oil and gas corporations listed on NYSE, and evidence supports a significant positive impact of oil price shocks on stock returns in the short-run. Bastianin et al. (2016) also study the effects of crude oil price shocks on the stock market volatility of the G7 countries and find that stock market volatility does not respond to oil supply shocks but, on the contrary, react to demand shocks. The results suggest that relevant economic policies should focus on the source of the oil price shocks.

The current study observes that the common characteristic of the extant literature is the treatment of the oil and gas industry as a uniform entity, including when it clearly consists of dissimilar subsectors. Generally, the literature largely disregards the upstream and downstream dichotomy in firms' specialization along the oil and gas supply chain. The upstream subsector consists of firms in petroleum exploration and drilling, and the downstream segment covers firms in storage and transportation, primary and secondary distribution and marketing of refined products (see Lima et al., 2016). Specifically, the previous analysis ignores niches of operational specialty in the chain as well as differing capital structures, leverage and risk profiles of these non(vertically) integrated firms in the supply chain. For example, capital structure, input costs and physical equipment utilized by firms in drilling (upstream sector) are likely to be different and more 'sunk' than their counterparts in the retail and marketing of oil products (downstream). Nevertheless, studies such as Cho (2013) and Zhu et al. (2016) suggest that explaining such distinction between upstream and downstream matters in pricing and supply chain profitability of oil firms.

Therefore, on the basis of the foregoing, we argue that explaining upstream-downstream dichotomy matters in the stock valuation of these oil firms. We contend that, similar to the demand and supply of oil shocks exert dissimilar impacts in the oil-stock nexus (see for example Kilian and Park, 2009; Bastianin et al., 2016), changes in crude oil prices are likely to have differential impacts on the stock prices and investment prospects of firms in the upstream and downstream sectors of the oil supply chain. In other words, the response of stock prices of firms in upstream and downstream segments to movements in oil prices may not be similar; therefore, investors 
should not assume homogenous expectations in relation to the risk associated with firms in the two sectors.

The goal of this paper is to investigate the upstream-downstream firm-level dichotomy in the stock price response to crude oil price movements among firms in the oil supply chain. This idea is vital to understanding debates relating to the "homogenous expectation" of returns and variances of the stocks of firms operating in the oil supply chain (Bogue and Roll, 1974, Levy and Levy, 1996). This idea is also important to investors and portfolio managers seeking to diversify their portfolios, as well as for capital budgeting purposes.

The model employed in this study is motivated by the Arbitrage Pricing Theory; thus, we are also able to capture the exposure of the stock returns of the nonintegrated oil firms to foreign exchange, interest rate and macroeconomic risks. Nevertheless, the magnitude of oil price volatility transmission may be tempered by some macrofinancial variables such as those noted. Since we are using firm-level data, our econometric analyses are in accordance with the nonstationary heterogeneous panel framework, which is suitable for large $\mathrm{N}$ and large $\mathrm{T}$ panels. Both the long-run and short-run responses of these two sectors to changes in oil price are evaluated. For the asymmetric version, we apply the Shin et al. (2014) approach to decompose the oil prices into positive and negative changes (i.e., upward and downward swings in oil price). The implications of our empirical findings for investors, as well as policy makers, are well documented in the paper.

The remainder of this paper is structured as follows; the next section briefly discusses integrated and nonintegrated forms in the oil supply chain. Section 3 explains the theoretical framework and the econometric model for the oil price-stock nexus. Section 4 describes the data used for estimation and renders preliminary analyses. In Section 5, we present and discuss the regression results including diagnostics and robustness tests. Section 6 concludes the paper.

\subsection{Integrated and nonintegrated firms in the oil supply chain}


The global oil and gas supply business environment is dominated by large (vertically) integrated multinational corporations (often referred to as "supermajors") ${ }^{1}$ and state-controlled national oil companies (NOCs) $)^{2}$. The business activities of supermajors and NOCs often span the entire length of the supply chain including prospecting, drilling and excavation of oil, exploration and production, storage and transportation and retail and marketing of oil products. Moreover, the financials of large integrated oil firm are highly visible to investors and a wide range of other stakeholders. For example, all top seven "Big Oil" firms have large market cap listings on the stock exchanges of their host nations and are listed in G7 countries, which have strong corporate governance and legal systems. Operationally, the activities of large integrated oil firms tend to span many countries on different continents with possible international diversification benefits (Switzer and Tahaoglu, 2015).

However, the oil companies' smaller nonintegrated counterparts specialize in activities in upstream or downstream sectors of the oil supply chain. For example, highly technical operations such as seismic scanning, offshore prospecting for oil and gas, and underwater drilling require firms with a high degree of "asset specificity" with wider financing, governance and capital structure implications (see Whyte, 1994; Choate, 1997; Mǒcnik, 2001; Vilasuso and Minkler, 2001; Hall, 2012). Consequently, NOCs and integrated oil companies tend to outsource or subcontract technical operations to smaller nonintegrated companies that specialize in those types of operations (Choate and Maser, 1992). Upstream sector firms specialize in activities such as drilling, exploration and production, while their downstream counterparts are involved in activities such as pipelines, refining and marketing of oil and gas and related products. In contrast to the larger integrated firms, the activities of nonintegrated oil firms are less visible to investors and have therefore garnered very limited focus in the literature. Therefore, we intend to fill the gap in the literature on the response of asset prices of nonintegrated firms in upstream and downstream sectors of the supply chain to oil prices as well as other macroeconomic shocks in this paper.

\subsection{The stock market, oil price and macroeconomic variables}

\footnotetext{
${ }^{1}$ Often referred to as 'big oil' consisting of large integrated publicly owned oil firms including ExxonMobil (U.S., S\&P100, NYSE), British Petroleum (UK, FTSE100, LSE), Royal Dutch Shel 1(UK \& The Netherlands, FTSE100, LSE), Chevron Corporation (U.S., S\&P100, NYSE), ConocoPhillips (U.S., S\&P100, NYSE), Total SA(France, CAC 40, Euronext, NYSE) and Eni SpA( Italy, Borsa Italiana, LSE).

${ }^{2}$ For example, the so-called "new seven sisters" and many other state-controlled oil firms described in the Carola Hoyes article in Financial Times on March 12, 2007.
} 
The seminal paper by Campbell (1991) situates stock fundamentals around macroeconomic variables and accentuates the role of the crude oil price in the relationship. Consequently, the literature is replete with evidence of the relationship between oil price and economic activity (see Gupta, 2016 for an extensive review). In addition, evidence in the extant literature suggest that oil price shock is one of the main drivers of macroeconomic and financial variables such as business cycle, real activity (industrial production), and inflation (see for example Ewing and Thompson, 2007; Hamilton, 2011; Bodenstein et al., 2012; Peiro, 2016; Ratti and Vespignani, 2016; Kang et al., 2017). Specifically, the literature also suggests that oil price shocks impact the stock market (see Conrad et al., 2014; Salisu and Oloko, 2015; Gupta, 2016; Kang et al., 2017; for a review of the literature). The knowledge of this relationship is essential for targeting macroeconomic and energy policies and useful for investors when making investment decisions on possible portfolio diversification in the presence of oil risks (see Bastianin et al., 2016).

The pricing of risky assets such as stocks has dominated discussions in finance. The underlying intuition is that returns from financial assets are accompanied by risks; therefore, investors and fund managers need information regarding the nature and sources of risks that may affect asset returns. The theoretical basis for tying the nexus between stock price with oil price and other macroeconomic variables lies in the Arbitrage Pricing Theory (APT) (see Ross, 1976). The theory links the expected return of financial assets with the associated risk factors of the asset. The APT model seeks to explain asset returns through different unknown but identifiable factors (see Peiro, 2016). In modeling stock returns, the APT allows for multiple risk factors including macroeconomic risks and industry-specific characteristics. In essence, the APT provides a framework that captures the different sources of systematic risk by splitting this risk into its various components. However, the APT is not explicit regarding the specific quantitative factors underlying common stock returns. Thus, we complement our choice of risk factors with relevant theoretical discussions. Therefore, we provide the underlying theoretical motivation for each of these factor risks in subsequent subsections.

\subsection{Stock returns and Oil price}

The exposure of the nonintegrated oil firms to oil price risk can be explained from the cash flow hypothesis by Jones and Kaul (1996) and the supply- and demand-side hypotheses by Kilian and Park (2009). The cash flow hypothesis assumes that the oil price can affect the stock price directly 
by impacting on future cash flows or indirectly through the interest rate used to discount the future cash flows. Using the interest rate channel, higher oil prices may lead to the overestimation of the expected inflation and thus higher nominal interest rates; since discount rates are negatively related with stock prices, increases in interest rates depress stock prices (Rafailidis and Katrakilidis, 2014). In other words, in the spirit of the cash flow hypothesis, the relationship between oil price and stock returns is negative.

Conversely, the demand- and supply-side hypotheses of Kilian and Park (2009) assume that the response of stock price to oil price changes can be either positive or negative, depending on whether the changes in oil price are driven by demand- or supply-side shocks. For instance, the stock returns can respond negatively to oil price shocks if the shocks arise from the uncertainty about future crude oil supply shortfalls. However, the response will be positive if the shocks are driven by an unanticipated global expansion (see also Apergis and Miller, 2009). In addition to oil price, we also explain other macroeconomic variables that have been validated as risk factors for explaining stock returns. The prominent among these variables are the following: GDP growth or growth of industrial production to measure the exposure of stocks to a business cycle (see Humpe and Macmillan, 2007; Tsagkanos and Siriopoulos, 2015 for a review); exchange rate to measure exposure to foreign exchange risk (see Salisu, and Oloko, 2015; Wong, 2017 for a review); inflation to measure macroeconomic uncertainty (see Tiwari et al., 2015 for a review); and interest rate spread to capture interest rate risk (see Papadamou et al., 2017 for a review). Like the oil price and stock returns nexus, we also justify the inclusion of other macroeconomic risks both theoretically and empirically as highlighted in subsequent subsections.

\subsection{Stock returns and inflation}

There are three hypotheses that appear to have emerged in relation to the stock returns-inflation nexus. These hypotheses are the Fisherian hypothesis, the Hedge hypothesis and the Demand hypothesis arising from the "proxy effect". The first two hypotheses are discussed simultaneously as the validity of one implies the validity of the other. The Fisherian hypothesis assumes neutrality of real stock returns to rising inflation, while the Hedge hypothesis assumes a positive relationship between nominal stock return and inflation. This hypothesis indicates whether the Fisherian hypothesis is valid, then the positive relationship between nominal stock returns and inflation is not in doubt. Thus, the difference in the hypothesis lies in the proxy for stock returns. In essence, 
in testing for the validity of the Fisherian hypothesis, one is required to use the real stock return, and the coefficient on inflation is not expected to be significant. However, in testing for the validity of the hedging property of inflation, the nominal stock return is used, and the resulting coefficient on inflation is then examined to verify the hedging property of inflation. A positive and significant coefficient on inflation implies that the nominal stock return currently subsumes the rising inflation, and the risk (inflation) adjusted stock return is expected to be inflation neutral. These two hypotheses are premised on the fact that investors in the stock market are fully compensated for upward movements in the general price level through corresponding increases in the nominal stock market returns; thus, the real returns remain independent and unaffected (see Tiwari et al., 2015).

However, a number of studies have rejected the Fisherian hypothesis and reported a negative relationship between stock return and inflation (see for example, Linter, 1975; Fama, 1981; Geske and Richard, 1983 and Asprem, 1989), thus rejecting the Fisherian hypothesis and by implication renders the hedge hypothesis invalid. These conflicting findings may be as a result of the measure for inflation. For instance, Chatrath et al. (1996) note that the real stock returns serve as a perfect hedge (as in the case of Fisherian and Hedge hypotheses) if the expected component of inflation is used, while the unexpected component of inflation shows a negative relationship between real stock return and inflation (see also Tiwari et al., 2015). The argument in support of this negative relationship stems from the Demand hypothesis, which establishes a negative relationship between demand and price. For instance, an unexpected increase in inflation affects the purchasing power of the currency in question, which consequently causes the demand for goods

to decline. With the decline in demand, revenues and profits will also decline and, by extension, the overall economy slows including the stock market. This notion is also described as the "proxy effect" by Fama (1981) since the negative relation between stock return and inflation is inferred from the negative effect of the latter on real economic activity.

\subsection{Stock returns and real economic activity}

The theoretical relationship between stock returns and real economic activity is often anchored on the demand-side shock, which suggests a positive relationship between stock returns and growth in industrial production (a prominent proxy often used in the literature to capture real economic 
activity). For instance, if a positive productivity shock (that is originating from the respective positive demand shock) hits the industrial sector, the increase in production leads to higher revenues and profits, which causes an increase in dividends and, therefore, stock prices (Tsagkanos and Siriopoulos, 2015).

\subsection{Stock returns and interest rate}

The relationship between stock returns and interest rate has been explained from two perspectives: the wealth effect and the substitution effect. These two effects are consistent with the postulations by Friedman (1988) regarding the nature of the relationship between the money market and the stock market. The wealth effect assumes a positive relationship between stock prices and money; that is, a decrease in money demand (possibly as a result of a higher rate of return on treasury bonds/bills) reduces the demand for stocks. Consequently, a negative relationship is expected between the interest rate and stock returns. This negative association can also be explained from the perspective of the cash flow hypothesis, which establishes that a higher nominal interest rate (possibly as a result of monetary policy tightening) will depress stock prices since the former is used to discount the future cash flows.

For the substitution effect, a negative relationship between the two money and stock price is assumed to be negative. This finding is underscored by the observation that a decrease in the return on treasury bill/bond will lead to an increase in the demand for stocks that consequently leads to an increase in the stock returns.

\subsection{Stock returns and exchange rate}

The only prominent theoretical model often used to explain how exchange rate impacts on the behavior of stock returns is the Flow model proposed by Dornbusch and Fischer (1980). This model assumes a positive relationship between stock returns and the exchange rate. For example, if the exchange rate of a home country depreciates, this will enhance its trade competitiveness, which leads to an increase in the country's production, profits, and by extension, stock returns, where the stock return is defined as the net present value of the future cash flow of a company (Salisu and Oloko, 2015). In other words, the depreciation of the real exchange rate will increase the real stock price, while appreciation of the real exchange rate will decrease the real stock price (see Dornbusch and Fischer, 1980; Pan et al., 2007; Ülkü and Demirci, 2012; Wong, 2017). 
It is important to note the findings in the literature differ in terms of how these macroeconomic variables have been able to explain the behavior of stock returns. However, we argue that the nature of the stocks or portfolio under consideration may affect how the stock prices respond to macroeconomic factors. We are of the opinion that oil-related stocks are more likely to be driven by macroeconomic factors as long as energy continues to serve as a major input to production processes.

\subsection{The Model and Estimation Procedure}

As previously noted, our empirical model hinges on the APT, which allows us to capture different risk factors including oil price changes in the stock model. Specifically, we add other relevant macroeconomic variables that have been theoretically and empirically validated as important drivers of stock market behavior. This finding is important for producing robust estimates about the possible spillover transmission between the oil price and the stock prices of nonintegrated oil firms.

A typical representation for the APT assumes that investors believe that the $n \times 1$ vector, $r$ , of the single-period random returns on capital assets satisfies the factor model given below (see Huberman and Wang, 2005):

$$
r=\alpha+\beta f+\varepsilon,
$$

where $\alpha$ is an $n \times 1$ vector of the constants; $f$ is a $k \times 1$ vector of random variables (factors); $\beta$ is an $n \times k$ matrix of beta or factor loading; and $\varepsilon$ is an $n \times 1$ vector of disturbances. The model has assumed that $E(f)=0$ and $E(\varepsilon)=0$ where 0 denotes the vector of zeros with the corresponding dimension for $f$ and $\varepsilon$. Consequently, $E(r)=\alpha$. These assumptions are realizable if the factors are correctly specified. For instance, if we assume that a series, $x_{t}$, exhibits a unit root (which is a prominent feature of most economic series including those that are used in this study), $E\left(\Delta x_{t}\right)=0,{ }^{3}$ which explains why macroeconomic variables in the APT model are expressed in either a difference form or in the form of a rate of change. In other words, specifying the macroeconomic variables in this manner ensures the validity of the APT assumptions.

\footnotetext{
${ }^{3}$ Note that a series is assumed to exhibit a unit root if $x_{t}$ is given as $x_{t}=\rho x_{t-1}+v_{t}$ and $\rho=1$ such that $x_{t}-x_{t-1}=\Delta x_{t}=v_{t} \sim\left(0, \sigma^{2}\right) ;$ therefore, $E\left(\Delta x_{t}\right)=0$.
} 
Thus, in this study, we consider the Panel Autoregressive Distributed Lag (PARDL) model of Pesaran and Smith (1995) and Pesaran et al. (1997, 1999), which allows for the estimation of both long run and short run responses of nonintegrated oil firms' stock prices to oil price shocks. Since the firms are grouped into Upstream and Downstream sectors, we expressed the ARDL in panel form. This version of panel regression hinges on the nonstationary heterogeneous panel regression model. There are three interesting features of this model that appear to align with the objectives of this paper and the underlying assumptions of the APT. First, the model allows for nonstationarity, which is envisaged given the nature of the economic series being analyzed. In other words, the model is used where nonstationarity is a concern. In addition, the assumption of nonstationarity for the underlying series helps us to validate the applicability of the APT as previously highlighted. Second, the model allows for a degree of heterogeneity in the slope coefficients, which is inevitable in the estimation given the nature of cross-sections being examined. We argue that the investors in the Upstream and Downstream sectors may not exhibit homogenous expectations about their stock returns in the presence of oil price risk; therefore, it becomes imperative to capture any inherent heterogeneity in the beta or factor loading. Finally, the model is suitable for large $\mathrm{N}$ and large $\mathrm{T}$ panels. Both the long-run and short-run responses of these two sectors to oil price are evaluated. As previously noted, we also explain the nonlinearity in oil price using the Shin et al. (2014) approach (see also Salisu and Isah, 2017). This explanation allows us to capture the response of stock prices to positive and negative changes in oil price.

The generic representation for the Panel ARDL model in accordance the Pesaran and Smith (1995) and Pesaran et al. $(1997,1999)$ is expressed below:

$$
y_{i t}=\sum_{k=1}^{p} \lambda_{i k} y_{i, t-k}+\sum_{j=0}^{q} \psi_{i j}^{\prime} X_{i, t-j}+\mu_{i}+\varepsilon_{i t} ; i=1, \ldots, N ; t=1, \ldots, T .
$$

where $i$ is the number of individual firms (cross-sections); $t$ is the number of periods (time dimension); $\mu_{i}$ is the firm effects; $\varepsilon_{i t}$ is the panel disturbance term; $X_{i t}$ is a $k \times 1$ vector of explanatory variables; $\psi_{i j}^{\prime}$ are the $1 \times k$ coefficient vectors; and $\lambda_{i j}$ are scalars. For the cointegrated series of order 1 [i.e., $I(1)$ ], the error term is expected to be integrated of order zero [i.e., $I(0)$ ]. Thus, the error correction representation of equation (2) can be written as:

$$
\Delta y_{i t}=\rho_{i}\left(y_{i, t-1}-\phi_{i}^{\prime} X_{i t}\right)+\sum_{j=1}^{p-1} \lambda_{i j}^{*} \Delta y_{i, t-1}+\sum_{j=0}^{q-1} \psi_{i j}^{\prime *} \Delta X_{i, t-j}+\mu_{i}+\varepsilon_{i t}
$$


where $\rho_{i}=-\left(1-\sum_{j=1}^{p} \lambda_{i j}\right)$ is the speed of adjustment; $\phi_{i}=\sum_{j=1}^{p} \lambda_{i j} /\left(1-\sum_{k} \lambda_{i k}\right)$ is a vector of longrun parameters, while $\lambda_{i j}^{*}=-\sum_{m=j+1}^{p} \lambda_{i m}$ and $\psi_{i j}^{*}=-\sum_{m=j+1}^{q} \psi_{i m}$ are the short-run parameters. This parameter is expected to be significantly negative under the prior assumption that the variables show a return to a long-run equilibrium (Blackburne and Frank, 2007). In accordance with equation (3), we can write the estimable Linear PARDL model for this study as follows:

$$
\begin{gathered}
\Delta s_{i t}=\alpha_{0 i}+\beta_{1 i} s_{i, t-1}+\beta_{2 i} p_{t-1}+\beta_{3 i} e_{t-1}+\beta_{4 i} y_{t-1}+\beta_{5 i} i_{t-1}^{d}+\beta_{6 i} \pi_{t-1}+\sum_{j=1}^{N 1} \psi_{1 i j} \Delta s_{i, t-j}+\sum_{j=0}^{N 2} \psi_{2 i j} \Delta p_{t-j} \\
+\sum_{j=0}^{N 3} \psi_{3 i j} \Delta e_{t-j}+\sum_{j=0}^{N 4} \psi_{4 i j} \Delta y_{t-j}+\sum_{j=0}^{N 5} \psi_{5 i j} \Delta i_{t-j}^{d}+\sum_{j=0}^{N 6} \psi_{6 i j} \Delta \pi_{t-j}+\mu_{i}+\varepsilon_{i t} \\
i=1,2, N ; \quad t=1,2, \ldots, T .
\end{gathered}
$$

where $s_{i}$ is the log of stock price for each unit $i ; p$ denotes the log of oil price benchmark; $e$ is the $\log$ of real effective exchange rate; $y$ is the $\log$ of industrial production index; $i^{d}$ is the term structure computed as the difference between the long-term US Treasury bonds measured at period $t$ and the Treasury bill (short rate) in period $t-1$ (see Danthine and Donaldson, 2015); $\pi$ is the inflation rate measured by the log of consumer price index (therefore, we restrict the inflation to the anticipated component); $\mu_{i}$ is the group-specific effect; $i$ is the sampled units; and $t$ is the number of periods. ${ }^{4}$ For each cross-section, the long run slope (elasticity) coefficients are computed as $-\beta_{2 i} / \beta_{1 i},-\beta_{3 i} / \beta_{1 i},-\beta_{4 i} / \beta_{1 i},-\beta_{5 i} / \beta_{1 i}$ and $-\beta_{6 i} / \beta_{1 i}$ for oil price, exchange rate, output, interest rate and inflation, respectively. This calculation is derived under the assumption that, in the long run, $\Delta s=\Delta p=\Delta e=\Delta y=\Delta i^{d}=\Delta \pi=0$. This calculation is realizable if the model satisfies criteria for convergence, which can be evaluated using the error correction representation for equation (4) (this is discussed subsequently). The corresponding short-run estimates for the relevant variables are $\psi_{2 i j}, \psi_{3 i j}, \psi_{4 i j}, \psi_{5 i j}$ and $\psi_{6 i j}$ in the same order.

Note that the variables are expressed in first difference form in the short run as conventionally required; this somewhat guarantees the realization of the restrictions on the APT. Similarly, the re-parameterization of equation (4) through the error correction framework ensures

\footnotetext{
${ }^{4}$ In addition to the theoretical justification for the included variables in the model, our choice is consistent with the most significant variables in the Chen et al. (1986) paper, which explores the explanatory power of a wide class of factors before arriving with those captured in our model (see also Danthine and Donaldson, 2015).
} 
that the restrictions are also not violated in the long run (see equation (5) below). In other words, the model satisfies criteria for convergence and by implication also confirms the assumptions of APT in the long run if the coefficient on the error correction is negative, less than one in absolute terms and statistically significant. Thus, equation (2) is re-specified to include an error correction term as follows:

$$
\begin{aligned}
\Delta s_{i t}= & \beta_{i} v_{i, t-1}+\sum_{j=1}^{N 1} \psi_{1 i j} \Delta s_{i, t-j}+\sum_{j=0}^{N 2} \psi_{2 i j} \Delta p_{t-j}+\sum_{j=0}^{N 3} \psi_{3 i j} \Delta e_{t-j}+\sum_{j=0}^{N 4} \psi_{4 i j} \Delta y_{t-j} \\
& +\sum_{j=0}^{N 5} \psi_{5 i j} \Delta i_{t-j}^{d}+\sum_{j=0}^{N 6} \psi_{6 i j} \Delta \pi_{t-j}+\mu_{i}+\varepsilon_{i t}
\end{aligned}
$$

where $v_{i, t-1}=s_{i, t-1}-\phi_{0 i}-\phi_{1 i} p_{t-1}-\phi_{2 i} e_{t-1}-\phi_{3 i} y_{t-1}-\phi_{4 i} i_{t-1}^{d}-\phi_{5 i} \pi_{t-1}$ is the linear error correction term for each unit; the parameter $\lambda_{i}$ is the error-correcting speed of the adjustment term for each unit, which is expected to satisfy the criteria noted previously. The parameters $\phi_{0 i}, \phi_{1 i}, \phi_{2 i}, \phi_{3 i}, \phi_{4 i}$ and $\phi_{5 i}$ are computed as $-\alpha_{i} / \beta_{1 i},-\beta_{2 i} / \beta_{1 i},-\beta_{3 i} / \beta_{1 i},-\beta_{4 i} / \beta_{1 i},-\beta_{5 i} / \beta_{1 i}$ and $-\beta_{6 i} / \beta_{1 i}$ respectively.

As part of our objectives, we also decompose oil price shock into positive and negative shocks using the Shin et al. (2014) approach. Note that, in equations (4) and (5), there are no decompositions of oil price into positive and negative changes; hence, the impact of oil price shock under this situation is considered identical (i.e., symmetric). In the asymmetric case, we are able to evaluate whether it is important to explain asymmetries when addressing the oil price-stock nexus of a nonintegrated oil firm. This finding is particularly important for two reasons. First, we are able to examine whether the stock prices of both the Upstream and Downstream sectors are not linearly related to oil price or not. These instances are three possible cases in this regard: (i) symmetry in both sectors; (ii) asymmetry in both case; and (iii) asymmetry in one and symmetry in the other. Second, in connection with these classifications as in the latter, we are able to offer useful generalizations regarding the response of the Upstream and Downstream sectors of the nonintegrated oil firms to oil price shocks. Nonetheless, we consider baseline regression involving the full sample, which discards the separation of the sampled data into Upstream and Downstream sectors. This additional consideration helps to estimate the extent to which the estimates of the relationship between oil price and stock prices are over-estimated or under-estimated when we assume homogenous expectations. Thus, the asymmetric version of equation (4) is given as: 


$$
\begin{aligned}
\Delta s_{i t} & =\alpha_{0 i}+\beta_{1 i} s_{i, t-1}+\beta_{2 i}^{+} p_{t-1}^{+}+\beta_{2 i}^{-} p_{t-1}^{-}+\beta_{3 i} e_{t-1}+\beta_{4 i} y_{t-1}+\beta_{5 i} i_{t-1}^{d}+\beta_{6 i} \pi_{t-1}+\sum_{j=1}^{N 1} \psi_{1 i j} \Delta s_{i, t-j} \\
& +\sum_{j=0}^{N 2}\left(\psi_{2 i j}^{+} \Delta p_{t-j}^{+}+\psi_{2 i j}^{-} \Delta p_{t-j}^{-}\right)+\sum_{j=0}^{N 3} \psi_{3 i j} \Delta e_{t-j}+\sum_{j=0}^{N 4} \psi_{4 i j} \Delta y_{t-j}+\sum_{j=0}^{N 5} \psi_{5 i j} \Delta i_{t-j}^{d}+\sum_{j=0}^{N 6} \psi_{6 i j} \Delta \pi_{t-j}+\mu_{i}+\varepsilon_{i t}
\end{aligned}
$$

where $p_{t}^{+}$and $p_{t}^{-}$denote the positive and negative shocks, respectively, and they are computed as positive and negative partial sum decompositions of oil price changes as defined below (see Shin et al., 2014):

$$
\begin{aligned}
& p_{t}^{+}=\sum_{k=1}^{t} \Delta p_{i k}^{+}=\sum_{k=1}^{t} \max \left(\Delta p_{i k}, 0\right) \\
& p_{t}^{-}=\sum_{k=1}^{t} \Delta p_{i k}^{-}=\sum_{k=1}^{t} \min \left(\Delta p_{i k}, 0\right)
\end{aligned}
$$

There is evidence of asymmetry if the coefficients of $p_{t}^{+}$and $p_{t}^{-}$are significantly different from each other; otherwise, their effect on stock returns is considered identical.

For the purpose of estimation, we consider both the Mean Group (MG) and Pooled Mean Group (PMG) estimators, both of which are prominent estimators for nonstationary and heterogeneous dynamic panels. Consequently, we subject the results from these estimators to Hausman test. A nonrejection of the null hypothesis implies the adoption of the PMG estimator, while the rejection indicates the adoption of the MG estimator (Blackburne and Frank, 2007; Salisu and Isah, 2017; Salisu et al., 2017). In other words, the PMG estimator is the efficient estimator under the null, while the MG estimator is the efficient estimator under the alternative hypothesis (Blackburne and Frank, 2007; Salisu and Isah, 2017; Salisu et al., 2017). ${ }^{5}$

\subsection{Data and Preliminary Analyses}

Our data scope for the purpose of empirical analyses ranges from January 2000 to February 2017. For the nonintegrated oil firms, we were able to collect data on the stock prices of 102 Upstream firms (15 for Drilling and 87 for Exploration and Production) and 114 Downstream firms (45 Storage \& Transportation and 69 Retail and Marketing firms). Narayan and Bannigidadmath (2015) provide further justifications for the selection of firms using a range of financial variable

\footnotetext{
${ }^{5}$ All the regression results for both the MG and PMG estimators including relevant STATA codes used in this paper are available on request.
} 
predictors. In all, our data covers 216 nonintegrated oil firms. For the oil price, we consider the spot prices of three prominent benchmark crudes: West Texas Intermediate (WTI), Brent and Dubai Fateh. Essentially, we use the Brent sport price for the main analyses, while the other two global oil price proxies are used for robustness. Stock price data were sourced from Thomson Reuters, while the oil price data were obtained from the US Energy Information Administration.

This study used a sample of nonintegrated oil and gas supply companies registered in countries spanning six continents. The majority of the firms are listed in North America (mainly the U.S. and Canada); however, a discernible pattern is evident in the regional geographical concentration of stock market listings of firms in each sector and subsector. For example, 93\% of oil and gas drilling firms in the sample are registered in North America (53\% in the drilling sector are registered in the U.S., $40 \%$ are in Canada), and 7\% are registered in the Middle East (Israel only). For the exploration and production subsector, nearly $70 \%$ of companies are listed in North America (39.33\% in Canada and $30.33 \%$ in the U.S.); $19 \%$ are listed in Asia (China), $8 \%$ in Europe, $2 \%$ in Australia and New Zealand (equal proportion), and 1\% in South America (Argentina). The overall pattern of stock market-listed companies in oil and gas storage and transportation resemble that for exploration and production, although not exactly in country composition and proportion. Thirty-nine of the companies in this sector are listed in North America; 34\% are listed in Asia, 23\% in Europe, 2\% in the Middle East and 2\% in South America. In the retail and marketing subsector, $52 \%$ of the companies are listed in Asia (majority in Japan), $15 \%$ in North America (U.S. 13\%, Canada 2\%); 13\% are listed in Africa (Nigeria representing $7 \%$ ), and 12\% are listed in the Middle East, 3\% in Australia and New Zealand, and 3\% in South America.

Before the main estimation, we offer preliminary analyses such as descriptive statistics (mean and standard deviation) and panel unit root tests. Table 1 shows the descriptive statistics for the relevant variables in the model. A cursory examination of the table reveals that the upstream sector may have witnessed more of an upward trend in stock prices than the downstream sector, on average, judging by their mean values. In addition, the same pattern is observed for standard deviation. In other words, the upstream sector tends to exhibit a higher volatility than their downstream counterparts. This trend appears to attest to the norm in finance theory (on the basis of the CAPM), which assumes that the higher the risk, the higher the returns and vice versa. This norm is also upheld for the two components of each sector. For example, the exploration and 
production subsector of the upstream records a higher mean value and a higher standard deviation than the drilling subsector. Similarly, the storage and transportation subsector of the downstream sector, which records a higher mean value than the retail and marketing, also exhibits a higher volatility. This finding suggests the possibility of the midstream sector consisting of firms in drilling and storage and transportation, which have similar average mean values, albeit standard deviations. However, this study focuses on broad upstream versus downstream sector bifurcations of the supply chain and their corresponding subsectors. Thus, the distribution of the stock price data used for analyses in this paper appears to be consistent with theory. Similar conclusions appear to hold for oil prices; Brent has the highest mean and standard deviation values. In other words, the Brent crude price has witnessed more variations than the WTI and Dubai-Fateh over the period under consideration. We also find that the variations in the other variables (output, exchange rate and interest rate spread) are minimal, indicating that their movements have been fairly stable compared to the stock price and oil price.

\section{[Insert Tables $1 A$ and $1 B$ here]}

As a precondition for the choice of an empirical model involving large $N$ and large $T$ panels, we also conduct a panel unit root test for all variables in the model (see Table 2). We consider both the stationarity test (such as the Hadri, 2000 Lagrange Multiplier test) and the nonstationarity tests (such as the Im, Pesaran and Shin, 1997; Harris and Tzavalis, 1999; Breitung, 2000; and Levin, Lin and Chu, 2002 tests). The unit root test results for the stock prices are presented in Table 2A. We find that the stock prices of the Upstream sector including its components (Drilling and Exploration and Production) are integrated of order one [I(1)] regardless of the test type, while the results are mixed for the Downstream sector as well as its subsectors. For example, the HarrisTzavalis and the Im-Pesaran-Shin (IPS) unit-root tests indicate that the stock prices of the Downstream are $I(0)$; however, all the other tests suggest otherwise. The unit root test results for oil prices and other variables are presented in Table 2B. Similar to the upstream sector, the oil prices, with the exception of WTI, also exhibit $I(0)$ irrespective of the test employed. However, all the other variables depict a mixed order of integration. Since the underlying framework for estimation allows for the combination of both $I(0)$ and $I(1)$ (in so far as the level of stationarity 
does not exceed $I(1)$ ); thus, the mixed order of integration for certain variables in the model is not expected to bias our estimates. ${ }^{6}$

\section{[Insert Tables $2 A$ and $2 B$ here]}

\subsection{Results and Discussions}

We assess the impact of prices of three main crude oil benchmark (Brent, WTI and Dubai) on the stock prices of nonintegrated firms in the upstream and downstream sectors of the global oil supply chain controlling for the underlying effect of putative macroeconomic drivers of the stock-oil price relationship. The empirical strategy outlined in Section 3 explains the possible asymmetry in the stock-oil price nexus for firms in both sectors of the supply chain and for all three oil benchmarks. The empirical results are reported for each crude oil benchmark under two sectoral headings: upstream sector (drilling \& E\&P firms) and downstream sector (R\&M and S\&T firms), for cognate versions of the model without and with asymmetry for both the long- and shortrun controlling for the role macroeconomic drivers play in the global stock-oil price nexus in Tables 3 and 4, respectively. Similarly, Tables 5 and 6 contain the results of drilling and E\&P firms to facilitate intra-sector comparison of upstream firms; Tables 7 and 8 contain the results of R\&M and S\&T firms in the downstream sector.

The empirical estimations were prefaced with Hausman tests to establish a robust and efficient estimator for our data. The test results and their corresponding probabilities, in the bottom rows of Tables 3 to 8 , overwhelmingly reject the null hypothesis, lending support to the MG estimator for the majority of the inter-sector panels in Tables 3 and 4 and all the subsector panels in Tables 6 and 7. Specifically, the null hypothesis of Hausman tests was rejected for the results of each of the six panels in Tables 3, 4, 6 and 7, three subsector panels of six in Table 5, and two of six in Table 8. Therefore, for the results in columns (2), (4) and (6) of Table 5 and columns (2) and (4) of Table 8, we use the PMG estimates, while the remainder of the results are MG estimates.

\subsection{Stock price-oil price response- inter-sector results (sector panels)}

\footnotetext{
${ }^{6}$ Note that the panel cointegration test is suppressed here since the long run equilibrium can be easily verified from the speed of adjustment. As noted by Blackburne and Frank (2007), there is cointegration if the speed of adjustment parameter in equation (3) $\rho_{i}$ is significantly negative and less than one in absolute value.
} 
Tables 3 and 4 present the empirical results on the relationships between the stock prices of oil firms in the Upstream and Downstream sectors of the supply chain and benchmark crude oil prices and key macroeconomic variables without and with asymmetries, respectively. It should be noted that coefficients of long- and short-run relationships are presented in Panels A and B of each table, respectively. Much of the discussion in this section would focus on the stock price response to crude oil prices because the literature on the stock price- macroeconomic variable nexus is legion (see for example Ewing and Thompson, 2007; Henriques and Sadorsky, 2008; Narayan and Narayan, 2010; Sadorsky, 2012; Bondia et al., 2016; Raza et al, 2016, Salisu et al., 2017). The coefficients in the first column under Panel A of Table 3 show long-run adjustments of the stock prices of Upstream and Downstream firms' stock prices to prices of the three benchmark crude oils. The coefficients are statistically significant but show diametrically opposite directions of response (signs) for Upstream and Downstream firms' stock prices to crude oil prices in the longrun. Interestingly, the prices of all three benchmark crude oils exert upward pressure on the stock prices of firms in the Upstream sector but exert downward pressure on the stock prices of their Downstream counterparts. There are also notable differences in the (absolute) magnitude of elasticities of the stock price response to changes in the prices of different crude oils between the two sectors.

Specifically, the results show that, if the prices of Brent, WTI and Dubai crudes increase by $1 \%$, the stock price of upstream firms would, on average, increase by $0.75 \%, 0.87 \%$ and $0.54 \%$, respectively. However, a $1 \%$ increase in the prices of the three crudes contributes to a $0.20 \%$, $0.11 \%$ and $0.19 \%$, respectively, average decrease in the stock prices of downstream sector firms. In the long run, the oil price exerts a greater positive impact on the stock price of upstream sector firms in the supply chain. These results contrast with the negative and relatively smaller impact that oil price exerts on the stock price of downstream firms.

\section{[Insert Table 3 here]}

The short-run coefficients indicate instantaneous adjustments in changes of the stock price to short-run changes in benchmark crude oil prices and amidst changes underlying global macroeconomic variables. Noted in Table 3 is the reversal of the direction of the response from negative for long-run estimates in Panel A to positive for short-run in Panel B for downstream sector firms' stock response to Brent and WTI crude oil prices. However, this contrast is not replicated for Dubai crude, which retains a negative sign for the short and long run and is not 
noticed in upstream firms. However, the magnitude of impact varies in terms of short-run elasticities. For example, a 1\% increase in Brent crude prices in the short term, on average, led to a $0.22 \%$ increase in the stock prices of firms in the upstream sectors and a $0.06 \%$ increase in the stock prices of downstream sector firms. Similarly, the stock prices of Upstream and Downstream sector firms in the short term increased by $0.23 \%$ and $0.44 \%$, respectively, following a $1 \%$ increase in WTI crude prices. Overall, the above results show that oil prices have a greater positive shortand long-run impact on stock prices of firms in the upstream sector but a negative and relatively smaller impact on stock prices of their counterparts in the downstream sector.

We introduce asymmetry in the modeling framework to explain the possible effect of oil price shocks on the stock prices of firms operating in both sectors of the supply chain in results presented in Table 4. The coefficients in the top rows under Panels A and B of Table 4 show that both positive and negative oil price shocks exercised positive long- and short-run effects on the stock prices of upstream sector firms, which maintained upward momentum following shocks in the prices of all three crude oils. These results, in conjunction with those in Table 3, indicate that the stock prices of upstream sector firms display a symmetric response to oil price shocks. We further test for the possible identical impact of the positive and negative oil price changes in stock prices of the upstream sector firms using the Chi-square distributed Wald test for restrictions. The underlying null hypothesis for the test is that both asymmetric components of the oil price have an identical impact on the stock price, while the alternative hypothesis states otherwise (i.e., they do not have an identical impact). The results for the Wald test prominently confirm the presence of asymmetry in the oil-stock nexus for upstream sector firms, particularly in the long run. This finding appears to suggest that the upward and downward swings in oil price may create incentive or disincentive for firms in the sector, as these firms tend to react significantly to oil price swings. This finding further corroborates the actions of certain oil companies where they tend to reduce production during the period of a negative oil price shock or when they anticipate such a trend in the foreseeable future.

However, the direction of response of the stock prices of downstream firms to shocks in oil prices appears mixed for the three benchmark crude oil types. For Brent crudes, positive and negative price shocks exert concomitant positive and negative pressure on downstream sector firms' stocks in both the short and long run, albeit by statistically nonsignificant coefficients in the long run. However, both positive and negative shocks to WTI crude prices exert upward pressure 
on the stock prices of downstream sector firms in the long run, while stock price response mirrored positive and negative price shocks in the short run. For Dubai crude oil, positive and negative price shocks induced a downward trend in downstream sector firms' stock price in the long run, which contrasts with WTI but is a similar direction of response in the short-run. WTI crude is generally regarded as the bellwether of global crude oil prices by oil traders and researchers. These findings further raise a question regarding over-reliance on the WTI index, which implicitly assumes that the oil market is 'one great pool' (Adelman, 1984, p.5, Giulietti et al., 2014) and opens a debate on the weighted average for a global index.

\section{[Insert Table 4 about here]}

Similarly, the stock prices of downstream sector firms observed upward movement following positive shocks in Brent and WTI crude prices in both long- and short-run. However, positive shocks in Dubai crude prices exercised upward pressure on the stock prices of downstream sector firms in the short run but downward pressure in the long run. Moreover, there is a noticeable difference in the magnitudes of upstream and downstream sector firms' stock price response to positive and negative shocks in oil prices. For example, a positive shock leading to a $1 \%$ increase in Brent crude price in the long-run produced a $2 \%$ increase in the stock price of upstream sector firms but a far smaller $0.17 \%$ increase for their downstream counterparts. In contrast, a negative shock producing a $1 \%$ reduction in the Brent crude oil price induced a $0.4 \%$ increase in the stock price of upstream firms and a $0.1 \%$ decrease in the stock price of downstream sector firms. Notwithstanding, similar to the upstream sector, the stock prices of the downstream sector firms appear to respond asymmetrically to changes in the oil price, particularly when the Brent and WTI crude oil prices are used. In addition, the error correction terms accompanying short-run estimates in Panel B of Tables 3 and 4 are all negative and highly statistically significant. The negative and high statistically significant error correction coefficients suggest strong disequilibrium feedback emanating from long-run changes in oil price and macroeconomic variables impacting on the stock

prices of firms in both sectors of the supply chain, possibly indicating a cointegrating relationship in our model. In addition, the error correction terms imply that, in the short run, the stock price of firms in both sectors revert to equilibrium for all crude oils following a price shock. However, it is worthy to note that the corresponding error correction coefficients vary consistently between the two sectors. Specifically, the speed of adjustment for the downstream sector is faster than the 
upstream sector irrespective of the crude oil price, and it also remains valid for both symmetric and asymmetric panel ARDL models.

These contrasts in direction and scale of upstream and downstream firms' stock price response to shocks in oil price underscore marked sectoral dichotomy in the supply chain. The stock prices of firms in upstream and downstream sectors of the supply chain respond differently to the prices of different crude oils. These results imply that investors should not perceive assets of firms operating in upstream and downstream sectors of the oil supply chain as belonging to an analogous asset class with a similar risk profile for portfolio section purposes. Consequently, we argue that investors should not have a homogenous expectation of the variance of returns on the stock of firms in upstream and downstream sectors when underlying crude oil prices are considered.

\subsection{Stock price-oil price response- intra-sector results (subsector panels)}

The empirical results in Tables 5 and 6 compare the response of stock prices of Drilling and E\& $\mathrm{P}$ subsector firms (upstream sector) to changes in oil prices, while Tables 7 and 8 similarly compare R\&M and S\&T firms (downstream sector). The layout of results in the tables is similar to Tables 3 and 4; Tables 5 and 7 are based on models without asymmetry, while the results in Tables 6 and 8 explain asymmetry.

A discernible positive pattern generally remains for both Drilling and E\&P firms of the upstream sector in relation to their stock price response to changes in oil prices in the long-run, except the negative response of E\&P firms stocks to Dubai crude, albeit nonsignificant (see Table 5). The results in Panel B confirm strong positive comovement between the stock prices of both Drilling and E\&P firms with all benchmark crude oil prices in the short-run, which is similar to the upstream whole sample results. However, an interesting pattern is observed in the strength and magnitude of the long-run stock-oil price response between the two subsectors and among crude types. The elasticities of the response of the Drilling firms' stock prices are much larger than for E\&P firms for all three crude oil types and are statistically significant for both Brent and WTI crudes. Moreover, E\&P firms' stock prices displayed a significant response to the WTI benchmark but not to the Brent and Dubai benchmarks. When asymmetry is considered in the comparison, interesting results appear in Table 6. The magnitudes of long-run elasticities of the response of 
E\&P firms' stock prices are much larger than (nearly double) their Drilling counterparts for both positive and negative shocks in prices of all three crude benchmarks. However, the short-run responses of the stock prices of firms in the two sectors are similar. These results indicate that the stock prices of E\&P sector firms tend to respond more strongly to long-run shocks in oil prices. In addition, the Wald test shows evidence of asymmetry for both Drilling and E\&P firms in the long run, while the same is only noticed for Drilling in the short run with the exception of the WTI crude oil price. In other words, the response of E\&P stock prices to positive and negative changes in oil price is somewhat identical in the short run.

The theoretical and statistical interpretation of the influence of the error correction terms and macroeconomic control variables remain unchanged. The results in Tables 5 and 6 are in accordance with a priori expectations of the relationship between stock prices and macroeconomic variables, which largely conform to the existing literature.

Tables 7 and 8 report the results of models without and with asymmetry for both R\&M and S\&T firms, respectively. The results in Table 7 confirm a general long-run negative trend in the response of stock prices of R\&M and S\&T firms to oil prices shown in the whole sample results in Table 3. Specifically, R\&M responded significantly to Brent crude prices in the long run. However, in the short-run, S\&T firms' stock price co-movements with oil prices of the three benchmark crudes were positive and statistically significant. Nonetheless, R\&M sector firms stock prices respond negatively to Dubai benchmark crude oil prices in the short run. When asymmetry is introduced in the modeling framework, $R \& M$ and S\&T firms' stock price response to shocks (both positive and negative) in the prices of the three benchmark crudes in Table 8 is somewhat mixed. The coefficients on all the long-run estimates for S\&T firms' stock price response to positive shocks in all crude oils are generally positive but nonsignificant at the chosen levels of significance. However, R\&M firms' stock prices show contrasting positive and negative responses to positive shocks in the WTI and Dubai benchmark crude oil prices, respectively. Certain interesting patterns emerge for $\mathrm{R} \& \mathrm{M}$ and $\mathrm{S} \& \mathrm{~T}$ stock price responses to negative shocks in oil prices in Panel A of Table 8, albeit discernible statistical nonsignificance for all the coefficients. A negative shock to Brent and Dubai crude prices induced a decrease in stock prices for both R\&M and S\&T firms in the long run. However, a negative shock to the WTI crude price induced a rise in the stock prices of R\&M and S\&T firms in the long run. The short-run results in Panel B of Table 8 show two interesting and unequivocal patterns; first, positive shocks to prices of all crudes 
produced an increase in stock prices of $\mathrm{R} \& \mathrm{M}$ and $\mathrm{S} \& \mathrm{~T}$ firms, indicating that increases in oil prices benefit downstream sector firms in the short run. Second, negative shocks to oil prices of three benchmark crudes induce a negative response (decrease) in the stock price of R\&M firms but a positive response (decrease) in S\&T firms' stock price in the short run.

\subsection{Stock price - oil price response during pre- and post-global financial crisis periods}

We further extend our analyses to capture the role of changing market conditions. This extension involves restructuring the full data into two subsamples described as Pre- and Post-Global Financial Crisis (GFC) periods using September 2007 as a demarcation point. The choice of these two market conditions is motivated by the evidence in the literature indicating that the crisis significantly affected the behavior of stock returns (see for example, Anagnostidis et al., 2016; Jin, 2016). For instance, Jin (2016) find that most of the returns exhibit a long memory in the 2008 financial crisis period but not in the tranquil periods, indicating that the 2008 financial crisis has adversely affected the efficiency of Asian stock markets. In addition, Anagnostidis et al. (2016) note that, in periods of financial instability, the herding behavior of market agents may lead to abnormal price movements and, in turn, significant amounts of market inefficiency. Thus, we also

hypothesize differing responses of stock prices of both the upstream and downstream firms to changes in the oil price in tranquil and crisis periods.

\section{(A) Pre-GFC scenario and the Full Sample estimates}

We report the regression results for both the pre- and post-GFC periods in Tables 9 and 10, respectively. We find that the results for the symmetric scenario during the pre-GFC period are similar to the full sample estimates both in the long run and the short run. For instance, the response of stock price of the upstream sector firms to oil price changes is positive, while it is negative for the downstream sector. Similar to the full sample results, the magnitude of the long run impact of the oil price on stock returns is higher for the upstream than the downstream sector in absolute term, while the reverse is true in the short run. In addition, notice that the response of the firms' stock returns in the short run is similar; in essence, the firms respond in the same manner to sudden changes in the oil price since it is an unanticipated event. However, with time, the two sectors tend 
to diverge in their response. Furthermore, all the other variables are correctly signed, as in the full sample case, both in the long run and the short run.

For the asymmetric scenario, we are able to note the following. The positive (negative) oil price changes equally have positive (negative) effects on stock prices of the upstream sector both in the long run and short run, although the positive asymmetry impacts more in absolute value. For the downstream sector, both asymmetric oil prices have negative effects in the long run but positive effects in the short run. Negative asymmetry exerts more both in terms of magnitudes and statistical significance in the long run; however, the converse holds in the short run. This finding suggests that, during the period of tranquility, the investors in the two sectors exhibit heterogeneous expectations regarding stock returns regardless of the movements in oil price.

\section{(B) Post-GFC scenario and the Full Sample estimates}

The evidence obtained here appears to be a reverse of the pre-GFC case for the long run and short run relationships. In contrast to the pre-GFC, there appears to be a level of convergence in the long run between the upstream and the downstream sectors during the crisis period, while the response in the short run differs. On average, the stock returns of the firms in the two sectors appear to respond positively to changes in the oil price in the long run although the reaction is more pronounced for the upstream firms than their downstream counterparts. In addition, in terms of magnitude, the crisis appears to exert a greater impact on the stock returns of the two sectors relative to those obtained during the period of tranquility. However, in the short run, the stock market response to oil price changes varies between the two sectors; it is positive for upstream, while it is negative for downstream. Apparently, during the crisis period, which also led to a global economic slowdown, the sale of crude and refined oil, which predominantly lies within the purview of the downstream sector, also witnessed a downward trend.

When we explain asymmetry, stock returns of both upstream and downstream firms appear to respond identically to positive and negative oil price changes in the long run, while the result is mixed in the short run. Both the positive and negative oil price changes appear to have an identical (positive) impact on the upstream sector both in the long run and short run, although the response is greater in the long run than in the short run. Notwithstanding, the Wald test indicates the absence of asymmetry for the upstream sector both in the long run and short run. With the downstream sector, the long run coefficients are consistently positive regardless of the nature of oil price 
changes, similar to the upstream sector; however, it maintains an opposite (identical) effect in the short run. The asymmetry test also suggests the presence of asymmetry, albeit in the short run.

In sum, three findings are discernible from the results involving the GFC subsamples. First, the upstream and downstream sectors respond differently to changing market conditions. Second, the upstream firms react more to changing market conditions than their downstream counterparts. Third, regardless of the market condition, the downstream sector adjusts faster to the long-run equilibrium than their upstream counterparts in the presence of an oil price shock.

\subsection{Concluding remarks}

This study investigates the response of stock prices of nonintegrated oil and gas companies to changes in crude oil prices using three leading benchmark crudes (WTI, Brent and Dubai Fateh) in conjunction with the putative macroeconomic drivers of oil prices. The finding is motivated APT, which embraces the multiplicity of the risk confronting oil and gas stocks (including changes in oil prices), while the PARDL approach, which explains inherent persistence, heterogeneity and nonlinearity, is used to estimate the models.

The main conclusion from this study is that the stock prices of firms specializing in activities in the upstream and downstream sectors of the global oil supply chain respond in contrasting directions to long and short-run shocks in benchmark crude oil prices. Our results 
support Kang et al. (2017)'s conclusion that the "heterogeneous" of oil firms in different locations in the supply chain respond differently to "structural shocks" (p.1), although their study is based on three large-cap firms' pure play firms along the supply chain and on the aggregate stock return of firms. Uniquely, this study used and compared the returns on stocks for 216 firms listed on six continents. Another conclusion of our study is that firms in the upstream and downstream sectors tend to respond differently to changing market conditions caused by the Global Financial Crisis. Upstream firms tend to react more strongly to changing market conditions than their downstream counterparts; however, stocks of both sectors respond asymmetrically to changes in oil price irrespective of market conditions

The above findings imply that investors and fund managers should not perceive the assets of upstream and downstream sectors as a similar risk and return profile for portfolio diversification purposes. Therefore, we conclude that shocks to crude oil prices have differential impacts on the stock prices of firms in the upstream and downstream sectors of oil and gas supply and that stock prices of firms in the same sector respond uniformly to crude oil prices or have a homogenous expectation of variance and returns on the stock of firms in both sectors.

\section{References}

Adelman, M.A. (1984). International oil agreements. The Energy Journal, 5, 1-9.

Anagnostidis, P., Varsakelis, C. and Emmanouilides, C.J. (2016). Has the 2008 financial crisis affected stock market efficiency? The case of Euro zone. Physica A: Statistical Mechanics and its Applications, 447, 116-128.

Apergis, N. and Miller, S.M. (2009). Do structural oil-market shocks affect stock prices? Energy Economics, 31, 569-75.

Arouri, M. E. and Rault, C. (2010). Causal relationships between oil and stock prices: some new evidence from gulf oil-exporting countries. International Economics, 122, 41-56.

Asprem, M. (1989). Stock prices asset portfolio and macroeconomic variables in ten European countries. Journal of Banking and Finance, 13, 589-612.

Bastianin, A., Conti, F. and Manera, M. (2016). The impacts of oil price shocks on stock market volatility: Evidence from the G7 countries. Energy Policy, 98, 160-169 
Blackburne, E.F. and Frank, M.W. (2007). Estimation of nonstationary heterogeneous panels. The Stata Journal, 7:2, 197-208.

Bodenstein, M., Guerrieri, L. and Kilian, L. (2012). Monetary policy responses to oil price fluctuations. IMF Economic Review, 60(4), 470-504.

Bogue, M.C. and Roll, R. (1974). Capital budgeting of risky projects with "imperfect" markets for physical capital. The Journal of Finance, 29(2), 601-613.

Bondia, R., Ghosh, S. and Kanjilal, K. (2016). International crude oil prices and the stock prices of clean energy and technology companies: Evidence from non-linear cointegration tests with unknown structural breaks. Energy, 101, 558-565.

Boyer, M.M. and Filion, D. (2007).Common and fundamental factors in stock returns of Canadian oil and gas companies. Energy Econ. 29, 428-453

Breitung, J. (2000). The local power of some unit root tests for panel data. In: Baltagi, B.H. Nonstationary panels, panel cointegration and dynamic panels. Amsterdam, Elsevier, 16177.

Campbell, J.Y. (1991). A variance decomposition for stock returns. Economic Journal, 101, 157179.

Chatrath, A., S. Ramchander and F. Song (1995). The role of futures trading activity in exchange rate volatility. Journal of Futures Markets, 16, 561-84.

Chen, N.F., Roll, R. and Ross, S.A. (1986). Economic forces and the stock market. Journal of Business, 59, 383-404.

Cho, S.H. (2013). Horizontal mergers in multitier decentralized supply chains. Management Science, 60(2), 356-379.

Choate, G. M. (1997). The governance problem, asset specificity and corporate financing decisions. Journal of Economic Behavior \& Organization, 33(1), 75-90.

Choate, G. M. and Maser, S. M. (1992). The impact of asset specificity on single-period contracting. Journal of Economic Behavior \& Organization, 18(3), 373-89.

Conrad, C., Loch, K. and Rittler, D. (2014). On the macroeconomic determinants of long-term volatilities and correlations in U.S. stock and crude oil markets. Journal of Empirical Finance, 29(0), 26-40.

Danthine, J.P and Donaldson, J.B. (2014). Intermediate Financial Theory. Third Edition, Academic Press.

Diaz, E.M. and Perez de Gracia, F. (2017). Oil price shocks and stock returns of oil and gas corporations. Finance Research Letters, 20, 75-80

Ding, Z., Liu, Z., Zhang, Y. and Long, R. (2017). The contagion effect of international crude oil price fluctuations on Chinese stock market investor sentiment. Applied Energy, 187, 2736.

Dornbusch, R. and Fischer, S. 1980. Exchange rates and the current account. American Economic Review, 70(1), 960-971.

El-Sharif, I., Brown, D., Burton, B., Nixon, B., Russell, A., 2005.Evidence on the nature and extent of the relationship between oil prices and equity values in the UK. Energy Econ. 27, 819830.

Ewing, B.T. and M.A. Thompson (2007). Dynamic cyclical comovements of oil prices with industrial production, consumer prices, unemployment, and stock prices. Energy Policy 35(11), 5535-5540.

Fama, E.F. (1981). Stock returns, real activity, inflation and money. American Economic Review, 71, 545-565. 
Ftiti, Z., Guesmi, K. and Abid, I. (2016). Oil price and stock market co-movement: What can we learn from time-scale approaches? International Review of Financial Analysis, 46, 266-80.

Friedman, M. (1988). Money and the stock market. Journal of Political Economy, 96(2), 221-245.

Geske, R. and Richard, R. (1983). The fiscal and monetary linkage between stock returns and inflation. Journal of Finance, 38(1), 1-33.

Giulietti, M., Iregui, A.M. and Otero, J. (2014). Crude oil price differentials, product heterogeneity and institutional arrangements. Energy Economics, 46, 28-32.

Gupta, K. (2016). Oil price shocks, competition, and oil \& gas stock returns - Global evidence. Energy Economics, 57, 140-153

Hadri, K. (2000). Testing for stationarity in heterogeneous panel data. Economic Journal, 3(2), 148-161.

Hall, T. W. (2012). The collateral channel: Evidence on leverage and asset tangibility. Journal of Corporate Finance, 18(3), 570-83.

Hamilton, J.D. (2011). Nonlinearities and the macroeconomic effects of oil prices. Macroeconomic Dynamics. 15, 364-378

Harris, R.D. and Tzavalis, E. (1999). Inference for unit roots in dynamic panels where the time dimension is fixed. Journal of Economics, 91(2), 201-26.

Henriques, I. and Sadorsky, P. (2008). Oil prices and the stock prices of alternative energy companies. Energy Economics, 30(3), 998-1010.

Huang, R.D., Masulis, R.W. and Stoll, H.R. (1996). Energy shocks and financial markets. Journal of Futures Markets, 16, 1-27

Huberman, G. and Wang, Z. (2005). Arbitrage Pricing Theory. Federal Reserve Bank of New York Staff Reports. Staff Report no. 216.

Humpe, A. and Macmillan, P. (2007). Can macroeconomic variables explain long term stock market movements? A comparison of the US and Japan. Centre for Dynamic Macroeconomic Analysis Working Paper Series CDMA07/20.

Im. K.S., Pesaran, M.H. and Shin, Y. (1997). Testing for unit roots in heterogeneous panels. mimeo: Department of Applied Economics, University of Cambridge.

Jin, X. (2016). The impact of 2008 financial crisis on the efficiency and contagion of Asian stock markets: A Hurst exponent approach. Finance Research Letters, 17, 167-175.

Jones, C. and Kaul, G. (1996). Oil and the stock markets. Journal of Finance, 51, 463-491.

Kang, W., Perez de Gracia, F. and Ratti, R.A. (2017). Oil price shocks, policy uncertainty, and stock returns of oil and gas corporations. Journal of International Money and Finance, 70(1), 344-359

Kilian, L. and Park, C. (2009). The impact of oil price shocks on the U.S. stock market. International Economic Review, 50, 1267-1287.

Levin, A., Lin. C.F. and Chu, C.S.J. (2002). Unit root tests in panel data: asymptotic and finite sample properties. Journal of Economics, 108(1), 1-24.

Levy, M. and Levy, H. (1996). The danger of assuming homogeneous expectations. Financial Analysts Journal, 5, 65-70.

Lima, C., Relvas, S., Paula, A. and Barbosa-Póvoa, F.D. (2016). Downstream oil supply chain management: A critical review and future directions. Computers and Chemical Engineering, 92, 78-92

Linter, J. 1975. Inflation and security returns. Journal of Finance, 30, 259-280.

Močnik, D. (2001). Asset specificity and a firm's borrowing ability: An empirical analysis of manufacturing firms. Journal of Economic Behavior \& Organization, 45(1), 69-81. 
Narayan, P.K. and Bannigidadmath, D. (2015). Are Indian stock returns predictable? Journal of Banking \& Finance, 58, 506-531.

Narayan, P.K. and Narayan, S. (2010). Modelling the impact of oil prices on Vietnam's stock prices. Applied Energy, 87(1), 356-361.

Pan, M.S., Fok, R.C. and Liu, Y.A. (2007). Dynamic linkages between exchange rates and stock prices: evidence from East Asian markets. International Review of Economics and Finance, 16(4), 503-520.

Papadamou, S., Sidiropoulos, M. and Spyromitros, E. (2017). Interest rate dynamic effect on stock returns and Central Bank Transparency: Evidence from Emerging markets, Research in International Business and Finance, 39, 951-962

Pesaran, M. H., Y. Shin, and R. P. Smith (1997). Estimating long-run relationships in dynamic heterogeneous panels. DAE Working Papers Amalgamated Series 9721.

Pesaran, M. H., Y. Shin, and R. P. Smith (1999). Pooled mean group estimation of dynamic heterogeneous panels. Journal of the American Statistical Association, 94, 621-634.

Pesaran, M. H., and R. P . Smith (1995). Estimating long-run relationships from dynamic heterogeneous panels. Journal of Econometrics 68: 79-113.

Peiro, A. (2016). Stock prices and macroeconomic factors: Some European evidence. International Review of Economics and Finance, 41, 287-294

Rafailidis, P. and Katrakilidis, C. (2014). The relationship between oil prices and stock prices: a nonlinear asymmetric cointegration approach. Applied Financial Economics, 24(12), 793800.

Ramos, S.B. and Veiga, H. (2011). Risk factors in oil and gas industry returns: international evidence. Energy Economics, 33, 525-542.

Ratti, R.A. and Vespignani, J.L. (2016). Oil prices and global factor macroeconomic variables. Energy Economics, 59, 198-212

Raza, N., Jawad, H.S., Tiwari, A.K. and Shahbaz, M. (2016). Asymmetric Impact of Gold, Oil Prices and Their Volatilities on Stock Prices of Emerging Markets. Resources Policy, 49, 290-301.

Ross, S.A. (1976). The Arbitrage Theory of Capital Asset Pricing. Journal of Economic Theory, 13, 341-360.

Sadorsky, P. (1999). Oil price shocks and stock market activity. Energy Economics, 21(5), 449469.

Sadorsky, P. (2001).Risk factors in stock returns of Canadian oil and gas companies. Energy Economics, 23, 17-28.

Sadorsky, P. (2012). Correlations and volatility spillovers between oil prices and the stock prices of clean energy and technology companies. Energy Economics, 34(1), 248-255.

Sadorsky, P. (2014). Modeling volatility and correlations between emerging market stock prices and the prices of copper, oil and wheat. Energy Economics, 43, 72-89.

Salisu, A.A. and Isah, K.O. (2017). Revisiting the oil price and stock market nexus: A nonlinear Panel ARDL approach. Economic Modelling, 66, 258-271.

Salisu, A.A., Isah O.K., Oyewole, J.O. and Akanni, O.L. (2017). Modelling oil price-inflation nexus: The role of asymmetries. Energy, 125, 97-106.

Salisu, A.A. and Oloko, T. (2015). Modelling oil price-US stock nexus: A VARMABEKK-AGARCH approach. Energy Economics, 50(C), 1-12. 
Shin, Y. and Yu, B. and Greenwood-Nimmo, M. (2014). Modelling Asymmetric Cointegration and Dynamic Multipliers in a Nonlinear ARDL Framework. In W.C. Horrace and R.C. Sickles, Eds, Festschrift in Honor of Peter Schmidt, Springer.

Switzer, L. N. and Tahaoglu, C. (2015). The benefits of international diversification: Market development, corporate governance, market cap, and structural change effects. International Review of Financial Analysis, 42(Supplement C),76-97.

Tiwari, A.K., Dar, A.B., Bhanja, N., Arouri, M. and Teulon, F. (2015). Stock returns and inflation in Pakistan. Economic Modelling, 47, 23-31.

Tsagkanos, A. and Siriopoulos, C. (2015). Stock markets and industrial production in north and south of Euro-zone: Asymmetric effects via threshold cointegration approach. The Journal of Economic Asymmetries, 12, 162-172.

Ülkü, N. and Demirci, E. (2012). Joint dynamics of foreign exchange and stock markets in emerging Europe. Journal of International Financial Markets, Institutions and Money, 22(1), 55-86.

Vilasuso, J. and Minkler, A. (2001). Agency costs, asset specificity, and the capital structure of the firm. Journal of Economic Behavior \& Organization, 44(1), 55-69.

Whyte, G. (1994). The role of asset specificity in the vertical integration decision. Journal of Economic Behavior \& Organization, 23(3), 287-302.

Wong, H.T. (2017). Real exchange rate returns and real stock price returns. International Review of Economics and Finance, 49, 340-352.

Zhu, J., Boyaci, T. and Ray, S. (2016). Effects of upstream and downstream mergers on supply chain profitability. European Journal of Operational Research, 249, 131-143. 
Table 1: Descriptive statistics

Table 1A: Descriptive statistics for the stock prices of the Downstream \& Upstream sectors

\begin{tabular}{llll|lll}
\hline Statistics & Upstream & E\&P & Drilling & Downstream & S\&T & R\&M \\
\hline Mean & 26.096 & 26.654 & 22.863 & 16.352 & 21.574 & 12.946 \\
Std. Dev. & 148.817 & 160.858 & 22.531 & 35.922 & 36.948 & 34.819 \\
Observations & 20706 & 17661 & 3045 & 23142 & 9135 & 14007 \\
\hline
\end{tabular}

Note: The acronyms E\&P, R\&M and S\&T denote Exploration and Production, Retail \& Marketing and Storage \& Transportation firms, respectively.

Table 1B: Descriptive statistics for the oil prices of benchmark crudes and other variables

\begin{tabular}{|c|c|c|c|c|c|c|}
\hline \multirow[b]{2}{*}{ Statistics } & \multicolumn{3}{|c|}{$p_{t}$} & \multirow[b]{2}{*}{$y_{t}$} & \multirow[b]{2}{*}{$i_{t}^{d}$} & \multirow[b]{2}{*}{$e_{t}$} \\
\hline & Brent & WTI & Dubai & & & \\
\hline Mean & 65.392 & 62.906 & 62.525 & 98.964 & 0.445 & 108.787 \\
\hline Std. Dev. & 32.119 & 27.920 & 31.572 & 4.895 & 0.418 & 10.049 \\
\hline Observations & 203 & 203 & 203 & 203 & 203 & 203 \\
\hline
\end{tabular}

Note: $p_{t}, y_{t}, i_{t}^{d}$ and $e_{t}$ represent the oil price, output, interest rate spread and real effective exchange rate, respectively.

Table 2: Panel unit root tests

Table 2A: Panel unit root tests for stock prices

$\begin{array}{llllll}\text { Upstream } & \text { Drilling } & \text { E\&P } & \text { Downstream } & \text { R\&M } & \text { S\&T }\end{array}$

Null Hypothesis: unit root with common process

\begin{tabular}{lllllll}
\hline LLC & $-0.013^{\mathrm{b}^{* * *}}$ & $-47.7322^{\mathrm{b}^{* * *}}$ & $-0.015^{\mathrm{b}^{* * *}}$ & $-0.012^{\mathrm{b}^{* * * *}}$ & $-83.4462^{\mathrm{b}^{* * *}}$ & $-88.069^{\mathrm{b}^{* * * *}}$ \\
Breitung t-stat. & $-13.344^{\mathrm{b}^{* * * *}}$ & $-6.5401^{\mathrm{b}^{* * * *}}$ & $-13.483^{\mathrm{b}^{* * * *}}$ & $-8.3973^{\mathrm{b}^{* * *}}$ & $-7.9020^{\mathrm{b}^{* * * *}}$ & $-1.9876^{\mathrm{a}^{*}}$ \\
Harris-Tzavalis & $-0.044^{\mathrm{b}^{* * *}}$ & $-0.014^{\mathrm{b}^{* * *}}$ & $-0.041^{\mathrm{b}^{* * *}}$ & $-37.373^{\mathrm{a}^{* * *}}$ & $-38.363^{\mathrm{a}^{* * *}}$ & $-1.783^{\mathrm{a}^{* * * *}}$ \\
\hline
\end{tabular}

Null Hypothesis: unit root with individual unit root process

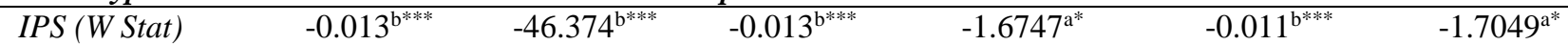

Null Hypothesis: no unit root with common unit root process

\begin{tabular}{lllllll}
\hline Hadri Z-stat. & $0.9117^{\mathrm{b}}$ & $-0.6312^{\mathrm{b}}$ & $1.133^{\mathrm{b}}$ & $-3.3557^{\mathrm{b}}$ & $-3.2884^{\mathrm{b}}$ & $0.5839^{\mathrm{b}}$
\end{tabular}

Note: $a$ and $b$ denote stationarity at level and at first difference, respectively; $* \mathrm{p}<0.05 ; * * \mathrm{p}<0.01 ; * * * \mathrm{p}<0.001$. The LLC denotes the Levin, Lin and Chu, 2002 test. All the stock price variables are expressed in natural logs.

Table 2A: Panel unit root tests for oil prices and other variables

\begin{tabular}{|c|c|c|c|c|c|c|c|}
\hline & \multicolumn{3}{|c|}{$p_{t}$} & \multirow[t]{2}{*}{$y_{t}$} & \multirow[t]{2}{*}{$i_{t}^{d}$} & \multirow[t]{2}{*}{$e_{t}$} & \multirow[t]{2}{*}{$\pi_{t}$} \\
\hline & BRENT & WTI & DUBAI & & & & \\
\hline \multicolumn{8}{|c|}{ Null Hypothesis: unit root with common process } \\
\hline$L L C\left(t^{*}\right)$ & $-0.015^{\mathrm{b}^{* * *}}$ & $-3.7516^{a^{* * *}}$ & $-0.014^{\mathrm{b}^{* * *}}$ & $-14.400^{\mathrm{a}^{* * *}}$ & $7.256^{a^{* * *}}$ & $-4.6903^{a^{* * *}}$ & $-16.431^{a^{* * *}}$ \\
\hline Breitung t-stat. & $-4.319^{\mathrm{b}^{* * *}}$ & $-4.483^{\mathrm{b}^{* * *}}$ & $-4.010^{\mathrm{b} * * *}$ & $-1.7949^{a^{*}}$ & $-1.4163^{\mathrm{a}^{*}}$ & $-2.5679^{\mathrm{b} * *}$ & $-4.355^{\mathrm{b}^{* * *}}$ \\
\hline $\begin{array}{l}\text { Harris-Tzavalis } \\
\text { (rho) }\end{array}$ & $-0.031^{\mathrm{b}^{* * *}}$ & $-0.029^{\mathrm{b}^{* * * *}}$ & $-0.028^{\mathrm{b}^{* * *}}$ & $-0.031^{b^{* * *}}$ & $-37.602^{\mathrm{a}^{* * *}}$ & $-0.027^{\mathrm{b}^{* * * *}}$ & $-0.027^{b^{* * *}}$ \\
\hline \multicolumn{8}{|c|}{ Null Hypothesis: unit root with individual unit root process } \\
\hline IPS (W Stat) & $-0.012^{\mathrm{b}^{* * *}}$ & $-55.728^{\mathrm{b} * * *}$ & $-0.01^{\mathrm{b}^{* * *}}$ & $-12.887^{\mathrm{a}^{* * *}}$ & $-2.305^{\mathrm{a}^{*}}$ & $-93.483^{\mathrm{b} * * *}$ & $-96.639^{b^{3}}$ \\
\hline \multicolumn{8}{|c|}{ iit root with common unit root process } \\
\hline Hadri Z-stat. & $-0.236^{\mathrm{b}}$ & $-2.505^{\mathrm{b}}$ & $-1.0948^{b}$ & $-3.7478^{b}$ & $-9.1170^{\mathrm{b}}$ & $9.2766^{* * * *}$ & $4.7878^{* * *}$ \\
\hline
\end{tabular}

Note: $a$ and $b$ denote stationarity at level and at first difference, respectively; $* \mathrm{p}<0.05 ; * * \mathrm{p}<0.01 ; * * * \mathrm{p}<0.001$. All the variables here are expressed in natural logs except $\boldsymbol{i}_{t}^{d}$. 
Table 3: Regression results (without asymmetry) for Upstream and Downstream sectors

\begin{tabular}{|c|c|c|c|c|c|c|}
\hline \multirow{2}{*}{$\frac{\text { Panel A }}{\text { Long-run }}$} & \multicolumn{2}{|c|}{ Using Brent } & \multicolumn{2}{|c|}{ Using WTI } & \multicolumn{2}{|c|}{ Using Dubai-Fateh } \\
\hline & Upstream & Downstream & Upstream & Downstream & Upstream & Downstream \\
\hline \multirow{2}{*}{$p_{t}$} & $0.754 * *$ & $-0.204^{*}$ & $0.872 * *$ & -0.018 & 0.535 & $-0.187 *$ \\
\hline & $(0.269)$ & $(0.096)$ & $(0.302)$ & $(0.088)$ & $(0.283)$ & $(0.091)$ \\
\hline \multirow{2}{*}{$e_{t}$} & $-2.841 * * *$ & $-4.828 * * *$ & $-2.584 *$ & $-3.923 * * *$ & $-3.796 * * *$ & $-4.719 * * *$ \\
\hline & $(1.078)$ & $(0.585)$ & $(1.203)$ & $(0.482)$ & (1.116) & $(0.561)$ \\
\hline \multirow{2}{*}{$y_{t}$} & $2.439 * * *$ & $2.316 * * *$ & $2.106^{* *}$ & $2.100 * * *$ & $2.704 * * *$ & $2.126 * * *$ \\
\hline & $(0.780)$ & $(0.397)$ & $(0.716)$ & $(0.389)$ & $(0.813)$ & $(0.390)$ \\
\hline \multirow[t]{2}{*}{$\pi_{t}$} & $-7.063 * * *$ & $-1.185 * *$ & $-6.966 * * *$ & $-1.268 * *$ & $-7.144 * * *$ & $-1.106^{*}$ \\
\hline & $(0.982)$ & $(0.440)$ & $(0.975)$ & $(0.431)$ & (1.004) & $(0.443)$ \\
\hline \multirow{2}{*}{$i_{t}^{d}$} & $-0.432 *$ & $-0.308 * * *$ & $-0.444 *$ & $-0.308 * * *$ & $-0.421 *$ & $-0.306 * * *$ \\
\hline & $(0.196)$ & $(0.049)$ & $(0.185)$ & $(0.047)$ & $(0.200)$ & $(0.050)$ \\
\hline \multicolumn{7}{|l|}{ Panel B } \\
\hline \multicolumn{7}{|l|}{ Short run } \\
\hline \multirow{2}{*}{$v_{t-1}$} & $-0.111 * * *$ & $-0.229 * * *$ & $-0.113 * * *$ & $-0.225 * * *$ & $-0.110 * * *$ & $-0.229 * * *$ \\
\hline & $(0.006)$ & $(0.015)$ & $(0.006)$ & $(0.014)$ & $(0.006)$ & $(0.015)$ \\
\hline \multirow[t]{2}{*}{$\Delta p_{t}$} & $0.211 * * *$ & $0.064 * * *$ & $0.231 * * *$ & $0.051 * * *$ & $0.224 * * *$ & $-0.055^{* *}$ \\
\hline & $(0.023)$ & $(0.016)$ & $(0.023)$ & $(0.015)$ & $(0.026)$ & $(0.020)$ \\
\hline \multirow[t]{2}{*}{$\Delta e_{t}$} & $-2.234 * * *$ & $-0.852 * * *$ & $-2.142 * * *$ & $-1.012 * * *$ & $-2.205 * * *$ & $-1.011 * * *$ \\
\hline & $(0.158)$ & $(0.182)$ & $(0.163)$ & $(0.181)$ & $(0.158)$ & $(0.180)$ \\
\hline \multirow{2}{*}{$\Delta y_{t}$} & 0.388 & $-1.066 * *$ & 0.321 & $-1.078 * *$ & 0.399 & $-0.875^{*}$ \\
\hline & $(0.246)$ & $(0.381)$ & $(0.247)$ & $(0.392)$ & $(0.245)$ & $(0.375)$ \\
\hline \multirow{2}{*}{$\Delta \pi_{t}$} & $3.088 * * *$ & -0.605 & $2.862 * * *$ & -1.150 & $3.347 * * *$ & 1.182 \\
\hline & $(0.743)$ & (1.024) & $(0.727)$ & (1.037) & $(0.720)$ & $(1.031)$ \\
\hline \multirow{2}{*}{$\Delta i_{t}^{d}$} & $-0.059 * * *$ & $0.067 * * *$ & $-0.063 * * *$ & $0.067 * * *$ & $-0.056 * * *$ & $0.062 * * *$ \\
\hline & $(0.010)$ & $(0.016)$ & $(0.010)$ & $(0.016)$ & $(0.010)$ & $(0.016)$ \\
\hline \multirow{2}{*}{$\alpha_{0}$} & $3.613 * * *$ & $5.293 * * *$ & $3.390 * * *$ & $4.358 * * *$ & $3.828 * * *$ & $5.247 * * *$ \\
\hline & $(0.608)$ & $(0.776)$ & $(0.617)$ & $(0.685)$ & $(0.614)$ & $(0.766)$ \\
\hline Hausman test & $21.6 * * *$ & $48.84 * * *$ & $25.32 * * *$ & $52.82 * * *$ & $54.16 * * *$ & $49.57 * * *$ \\
\hline$\chi_{k}^{2}[\mathrm{Prob}]$ & {$[0.000]$} & {$[0.000]$} & {$[0.000]$} & {$[0.000]$} & {$[0.000]$} & {$[0.000]$} \\
\hline$N$ & 102 & 114 & 102 & 114 & 102 & 114 \\
\hline$N T$ & 20,604 & 23028 & 20,604 & 23028 & 20,604 & 23028 \\
\hline
\end{tabular}

Note: $* \mathrm{p}<0.05 ; * * \mathrm{p}<0.01 ; * * * \mathrm{p}<0.001$. Nob is the number of observations. Values in ( ) and [ ] represent standard errors and probability values, respectively. The number of cross-sections and total panel observations are symbolized as $N$ and $N T$, respectively. The $\chi_{k}^{2}$ is the chi-squared statistic with $k$ degrees of freedom, which is determined by the number of estimated parameters in the long-run equation of the heterogeneous panel. 
Table 4: Regression results (with asymmetry) for Upstream and Downstream sectors

\begin{tabular}{|c|c|c|c|c|c|c|}
\hline \multirow{2}{*}{$\frac{\text { Panel A }}{\text { Long-run }}$} & \multicolumn{2}{|c|}{ Using Brent } & \multicolumn{2}{|c|}{ Using WTI } & \multicolumn{2}{|c|}{ Using Dubai-Fateh } \\
\hline & Upstream & Downstream & Upstream & Downstream & Upstream & Downstream \\
\hline \multirow{2}{*}{$p_{t}^{+}$} & $1.957 * * *$ & 0.165 & $2.091 * * *$ & $0.257^{*}$ & $1.358^{*}$ & -0.117 \\
\hline & $(0.307)$ & $(0.138)$ & $(0.305)$ & $(0.109)$ & $(0.534)$ & $(0.117)$ \\
\hline \multirow{2}{*}{$p_{t}^{-}$} & $0.408 *$ & -0.071 & $0.638 * * *$ & 0.083 & $0.781 *$ & -0.122 \\
\hline & $(0.190)$ & $(0.096)$ & $(0.189)$ & $(0.081)$ & $(0.333)$ & $(0.088)$ \\
\hline \multirow{2}{*}{$e_{t}$} & $-3.961 * * *$ & $-4.439 * * *$ & $-3.927 * * *$ & $-3.832 * * *$ & $-3.384 * *$ & $-4.552 * * *$ \\
\hline & $(1.047)$ & $(0.559)$ & $(0.988)$ & $(0.463)$ & (1.164) & $(0.539)$ \\
\hline \multirow{2}{*}{$y_{t}$} & $8.677 * * *$ & $2.855^{* * * *}$ & $7.904 * * *$ & $2.528 * * *$ & $4.446 * * *$ & $2.201 * * *$ \\
\hline & $(0.932)$ & $(0.435)$ & $(0.890)$ & $(0.431)$ & (1.352) & $(0.440)$ \\
\hline \multirow{2}{*}{$\pi_{t}$} & $-38.084 * * *$ & $-6.320 * * *$ & $-35.411 * * *$ & $-5.051 * * *$ & $-19.146 * * *$ & -1.355 \\
\hline & (4.774) & $(1.584)$ & (4.481) & $(1.515)$ & $(5.220)$ & $(1.335)$ \\
\hline \multirow[t]{2}{*}{$i_{t}^{d}$} & $-0.413 * * *$ & $-0.304 * * *$ & $-0.321 * * *$ & $-0.316 * * *$ & -0.415 & $-0.327 * * *$ \\
\hline & $(0.085)$ & $(0.048)$ & $(0.084)$ & $(0.046)$ & $(0.224)$ & $(0.048)$ \\
\hline Long run & $50.92 * * *$ & $10.99 * * *$ & $49.25 * * *$ & $5.69 *$ & $5.89^{*}$ & 0.01 \\
\hline \multirow{2}{*}{$\begin{array}{l}\text { asymmetry test } \\
\text { Panel B: }\end{array}$} & {$[0.000]$} & {$[0.001]$} & [0.000] & [0.017] & {$[0.015]$} & [0.941] \\
\hline & & & & & & \\
\hline \multicolumn{7}{|l|}{ Short run } \\
\hline \multirow{2}{*}{$v_{t-1}$} & $-0.034 * * *$ & $-0.234 * * *$ & $-0.034 * * *$ & $-0.229 * * *$ & $-0.112)^{* * * *}$ & $-0.233 * * *$ \\
\hline & $(0.002)$ & $(0.015)$ & $(0.002)$ & $(0.014)$ & $(0.007)$ & $(0.015)$ \\
\hline \multirow{2}{*}{$\Delta p_{t}^{+}$} & $0.278 * * *$ & $0.294 * * *$ & $0.206 * * *$ & $0.323 * * *$ & $0.287 * * *$ & $0.183 * * *$ \\
\hline & $(0.036)$ & (0.040) & (0.038) & $(0.045)$ & $(0.036)$ & $(0.032)$ \\
\hline \multirow{2}{*}{$\Delta p_{t}^{-}$} & $0.165 * * *$ & $-0.174 * * *$ & $0.292 * * *$ & $-0.246 * * *$ & $0.152 * * *$ & $-0.244 * * *$ \\
\hline & $(0.038)$ & $(0.037)$ & $(0.040)$ & $(0.043)$ & $(0.040)$ & $(0.040)$ \\
\hline \multirow{2}{*}{$\Delta e_{t}$} & $-2.264 * * *$ & $-0.916 * * *$ & $-2.179 * * *$ & $-1.042 * * *$ & $-2.250 * * *$ & $-1.118 * * *$ \\
\hline & $(0.152)$ & (0.177) & (0.157) & $(0.178)$ & $(0.158)$ & (0.178) \\
\hline \multirow{2}{*}{$\Delta y_{t}$} & -0.055 & $-1.093 * *$ & -0.149 & $-1.210 * * *$ & 0.326 & $-0.762 *$ \\
\hline & $(0.207)$ & $(0.358)$ & $(0.204)$ & $(0.348)$ & $(0.262)$ & $(0.345)$ \\
\hline \multirow{2}{*}{$\Delta \pi_{t}$} & $3.329 * * *$ & 0.486 & $2.518 * * *$ & 0.294 & $3.575 * * *$ & 1.558 \\
\hline & $(0.684)$ & (1.061) & $(0.675)$ & (1.040) & $(0.710)$ & (1.038) \\
\hline \multirow{2}{*}{$\Delta i_{t}^{d}$} & $-0.059 * * *$ & $0.068 * * *$ & $-0.063 * * *$ & $0.068 * * *$ & $-0.055 * * *$ & $0.064 * * *$ \\
\hline & $(0.010)$ & $(0.016)$ & $(0.010)$ & $(0.016)$ & $(0.010)$ & $(0.016)$ \\
\hline \multirow{2}{*}{$\alpha_{0}$} & $5.985^{* * *}$ & $7.264 * * *$ & $5.566 * * *$ & $7.051 * * *$ & $5.644 * * *$ & $4.375^{* * * *}$ \\
\hline & $(0.420)$ & (1.519) & $(0.407)$ & (1.369) & (1.105) & (1.166) \\
\hline \multirow{2}{*}{$\begin{array}{l}\text { Short run } \\
\text { asymmetry test }\end{array}$} & $3.93 *$ & $46.92 * * *$ & 2.04 & $48.10 * * *$ & $6.01 *$ & $48.82 * * *$ \\
\hline & {$[0.048]$} & {$[0.000]$} & {$[0.153]$} & {$[0.000]$} & [0.014] & {$[0.000]$} \\
\hline \multirow{2}{*}{$\begin{array}{l}\text { Hausman test } \\
\chi_{k}^{2}[\text { Prob }]\end{array}$} & 11.42 & $37.90 * * *$ & 12.43 & $46.61 * * *$ & $35.59 * * *$ & $43.56 * * *$ \\
\hline & {$[0.0762]$} & {$[0.000]$} & [0.0762] & {$[0.000]$} & {$[0.000]$} & {$[0.000]$} \\
\hline$N$ & 102 & 114 & 102 & 114 & 102 & 114 \\
\hline$N T$ & 20,604 & 23028 & 20,604 & 23028 & 20,604 & 23028 \\
\hline
\end{tabular}

Note: $* \mathrm{p}<0.05 ; * * \mathrm{p}<0.01 ; * * * \mathrm{p}<0.001$. Nob is the number of observations. Values in ( ) and [ ] represent standard errors and probability values, respectively. The number of cross-sections and total panel observations are symbolized as $N$ and $N T$, respectively. The $\chi_{k}^{2}$ is the chi-squared statistic with $k$ degrees of freedom, which is determined by the number of estimated parameters in the long-run equation of the heterogeneous panel. The long run and short run asymmetry tests involve the Chi-square distributed Wald test. The test is used here to establish the equality or otherwise of the impact of positive and negative changes in the oil price on stock prices. Thus, the underlying null hypothesis for the test is that both asymmetric components of the oil price have an identical impact on the stock price, while the alternative hypothesis states otherwise (i.e., they do not have an identical impact). 
Table 5: Regression results without asymmetry for Drilling and Exploration \& Production firms of the Upstream sector

\begin{tabular}{|c|c|c|c|c|c|c|}
\hline \multirow{2}{*}{$\frac{\text { Panel A }}{\text { Long-run }}$} & \multicolumn{2}{|c|}{ Using Brent } & \multicolumn{2}{|c|}{ Using WTI } & \multicolumn{2}{|c|}{ Using Dubai-Fateh } \\
\hline & Drilling & $\mathbf{E \& P}$ & Drilling & $\mathbf{E \& P}$ & Drilling & $\mathbf{E} \& \mathbf{P}$ \\
\hline \multirow{2}{*}{$p_{t}$} & $0.626^{*}$ & 0.171 & $0.767 * *$ & $0.514 * *$ & 0.462 & -0.225 \\
\hline & $(0.294)$ & $(0.227)$ & $(0.282)$ & $(0.207)$ & $(0.291)$ & $(0.236)$ \\
\hline \multirow{2}{*}{$e_{t}$} & $-2.126^{*}$ & $-4.497 * * *$ & -1.754 & $-3.260 * *$ & $-2.967 *$ & $-6.259 * * *$ \\
\hline & $(1.045)$ & (1.248) & $(1.071)$ & $(1.078)$ & (1.304) & $(1.310)$ \\
\hline \multirow{2}{*}{$y_{t}$} & $3.174 * * *$ & $2.532 * *$ & $3.003 * * *$ & $1.977 * *$ & $3.573 * * *$ & $3.212 * * *$ \\
\hline & $(0.898)$ & $(0.861)$ & $(0.923)$ & $(0.789)$ & $(0.928)$ & $(0.906)$ \\
\hline \multirow[t]{2}{*}{$\pi_{t}$} & $-3.981 * *$ & $-7.848 * * *$ & $-3.830 * *$ & $-7.928 * * *$ & $-4.111 * *$ & $-7.597 * * *$ \\
\hline & (1.396) & $(0.558)$ & $(1.330)$ & $(0.510)$ & (1.409) & $(0.612)$ \\
\hline \multirow{2}{*}{$i_{t}^{d}$} & -0.211 & $-0.305 * *$ & $-0.238^{*}$ & $-0.271 * *$ & -0.206 & $-0.360 * * *$ \\
\hline & $(0.121)$ & $(0.097)$ & $(0.117)$ & $(0.090)$ & $(0.121)$ & $(0.105)$ \\
\hline \multicolumn{7}{|l|}{$\frac{\text { Panel B }}{\text { Short run }}$} \\
\hline \multirow{2}{*}{$v_{t-1}$} & $-0.142 * * *$ & $-0.033 * * *$ & $-0.145^{*} * *$ & $-0.034 * * *$ & $-0.139 * * *$ & $-0.032 * * *$ \\
\hline & $(0.024)$ & $(0.003)$ & $(0.022)$ & $(0.003)$ & $(0.023)$ & $(0.003)$ \\
\hline \multirow{2}{*}{$\Delta p_{t}$} & $0.179 * * *$ & $0.249 * * *$ & $0.211 * * *$ & $0.272 * * *$ & $0.186 * * *$ & $0.258 * * *$ \\
\hline & $(0.029)$ & $(0.028)$ & $(0.034)$ & $(0.028)$ & $(0.035)$ & $(0.031)$ \\
\hline \multirow{2}{*}{$\Delta e_{t}$} & $-2.340 * * *$ & $-2.259 * * *$ & $-2.190 * * *$ & $-2.197 * * *$ & $-2.329 * * *$ & $-2.222 * * *$ \\
\hline & $(0.285)$ & $(0.171)$ & $(0.281)$ & $(0.176)$ & $(0.282)$ & $(0.173)$ \\
\hline \multirow{2}{*}{$\Delta y_{t}$} & 0.452 & $0.404 * *$ & 0.338 & $0.417 * *$ & 0.486 & 0.357 \\
\hline & $(0.432)$ & $(0.201)$ & $(0.415)$ & $(0.203)$ & $(0.439)$ & $(0.200)$ \\
\hline \multirow[t]{2}{*}{$\Delta \pi_{t}$} & 1.057 & $3.158 * * *$ & 0.669 & $3.004 * * *$ & 1.491 & $3.291 * * *$ \\
\hline & (1.017) & $(0.775)$ & (1.003) & $(0.758)$ & (1.013) & $(0.759)$ \\
\hline \multirow{2}{*}{$\Delta i_{t}^{d}$} & 0.012 & $-0.074 * * *$ & 0.009 & $-0.079 * * *$ & 0.015 & $-0.069 * * *$ \\
\hline & $(0.025)$ & $(0.010)$ & $(0.025)$ & $(0.010)$ & $(0.025)$ & $(0.010)$ \\
\hline \multirow{2}{*}{$\alpha_{0}$} & $1.951 * * *$ & $1.647 * * *$ & 1.747 & $1.552 * * *$ & 2.262 & $1.782 * * *$ \\
\hline & $(0.604)$ & $(0.148)$ & $(0.667)^{* *}$ & $(0.142)$ & $(0.636) * * *$ & $(0.154)$ \\
\hline Hausman test & $22.48 * * *$ & 2.36 & $26.32 * * *$ & 2.63 & $16.33 * * *$ & 7.39 \\
\hline$\chi_{k}^{2}[\operatorname{Prob}]$ & {$[0.000]$} & [0.7967] & {$[0.000]$} & [0.757] & {$[0.0060]$} & [0.1929] \\
\hline$N$ & 15 & 87 & 15 & 87 & 15 & 87 \\
\hline$N T$ & 3,030 & 17,574 & 3,030 & 17,574 & 3,030 & 17,574 \\
\hline
\end{tabular}

Note: The variable E\&P denotes oil and gas exploration and production. $* \mathrm{p}<0.05 ; * * \mathrm{p}<0.01 ; * * * \mathrm{p}<0.001$. Nob is the number of observations. Values in ( ) and [ ] represent standard errors and probability values, respectively. The number of cross-sections and total panel observations are symbolized as $N$ and $N T$, respectively. The $\chi_{k}^{2}$ is the chi-squared statistic with $k$ degrees of freedom, which is determined by the number of estimated parameters in the long-run equation of the heterogeneous panel. 
Table 6: Regression results with asymmetry for Drilling and Exploration \& Production firms of the Upstream sector

\begin{tabular}{|c|c|c|c|c|c|c|}
\hline \multirow{2}{*}{$\begin{array}{c}\begin{array}{c}\text { Panel A } \\
\text { Long-run }\end{array} \\
\end{array}$} & \multicolumn{2}{|c|}{ Using Brent } & \multicolumn{2}{|c|}{ Using WTI } & \multicolumn{2}{|c|}{ Using Dubai-Fateh } \\
\hline & Drilling & $\mathbf{E} \& \mathbf{P}$ & Drilling & E\&P & Drilling & $\mathbf{E \& P}$ \\
\hline \multirow{2}{*}{$p_{t}^{+}$} & $1.393 * * *$ & $2.207 * * *$ & $1.052 * * *$ & $2.044 * * *$ & $1.095 * * *$ & $1.407 * *$ \\
\hline & $(0.395)$ & $(0.451)$ & $(0.230)$ & $(0.627)$ & $(0.202)$ & $(0.622)$ \\
\hline \multirow{2}{*}{$p_{t}^{-}$} & $0.815^{* *}$ & $1.144 * * *$ & $0.690 * * *$ & $1.294 * *$ & $0.738 * * *$ & $0.792 * *$ \\
\hline & $(0.314)$ & $(0.298)$ & $(0.148)$ & $(0.415)$ & $(0.123)$ & $(0.387)$ \\
\hline \multirow{2}{*}{$e_{t}$} & -1.646 & -1.764 & $-1.528^{*}$ & -1.915 & -1.187 & $-3.550 * *$ \\
\hline & (1.058) & (1.189) & $(0.751)$ & $(1.347)$ & $(0.659)$ & $(1.352)$ \\
\hline \multirow{2}{*}{$y_{t}$} & $4.588 * * *$ & $4.777 * * *$ & $3.897 * * *$ & $3.729 * *$ & $4.301 * * *$ & $4.423 * *$ \\
\hline & $(1.037)$ & $(1.237)$ & $(0.635)$ & $(1.264)$ & $(0.581)$ & (1.576) \\
\hline \multirow{2}{*}{$\pi_{t}$} & $-16.553 * * *$ & $-30.473 * * *$ & $-11.266 * * *$ & $-23.256^{* * *}$ & $-11.427 * * *$ & $-20.407 * * *$ \\
\hline & (3.830) & $(5.442)$ & $(3.071)$ & (5.691) & $(2.678)$ & $(6.086)$ \\
\hline \multirow{2}{*}{$i_{t}^{d}$} & -0.167 & -0.307 & $-0.249 * * *$ & -0.474 & $-0.252 * * *$ & -0.451 \\
\hline & $(0.102)$ & $(0.191)$ & $(0.067)$ & $(0.261)$ & $(0.061)$ & $(0.262)$ \\
\hline Long run & $14.42 * * *$ & $21.08^{* *}$ & $6.41 * *$ & $8.45 * *$ & $7.82 * *$ & $4.91 * *$ \\
\hline asymmetry test & {$[0.000]$} & {$[0.000]$} & [0.011] & {$[0.004]$} & [0.005] & {$[0.027]$} \\
\hline \multicolumn{7}{|l|}{ Panel B: } \\
\hline \multirow[t]{2}{*}{$v_{t-1}$} & $-0.146^{* * *}$ & $-0.110 * * *$ & $-0.073 * * *$ & $-0.109 * * *$ & $-0.076 * * *$ & $-0.107 * * *$ \\
\hline & $(0.024)$ & $(0.006)$ & (0.019) & (0.007) & $(0.022)$ & $(0.006)$ \\
\hline \multirow{2}{*}{$\Delta p_{t}^{+}$} & $0.252 * * *$ & $0.204 * * *$ & $0.239 * * *$ & $0.157 * * *$ & $0.357 * * *$ & $0.274 * * *$ \\
\hline & $(0.037)$ & (0.039) & $(0.059)$ & $(0.042)$ & $(0.046)$ & $(0.041)$ \\
\hline \multirow{2}{*}{$\Delta p_{t}^{-}$} & 0.024 & $0.139 * *$ & $0.229 * * *$ & $0.276 * * *$ & 0.049 & $0.181 * * *$ \\
\hline & $(0.056)$ & $(0.044)$ & $(0.051)$ & $(0.045)$ & $(0.069)$ & $(0.044)$ \\
\hline \multirow[t]{2}{*}{$\Delta e_{t}$} & $-2.339 * * *$ & $-2.184 * * *$ & $-2.339 * * *$ & $-2.110 * * *$ & $-2.590 * * *$ & $-2.216^{* * *}$ \\
\hline & $(0.281)$ & $(0.178)$ & $(0.323)$ & $(0.185)$ & $(0.322)$ & $(0.178)$ \\
\hline \multirow{2}{*}{$\Delta y_{t}$} & 0.040 & -0.050 & 0.512 & 0.112 & $0.741 * * *$ & 0.334 \\
\hline & $(0.346)$ & $(0.296)$ & $(0.555)$ & $(0.314)$ & $(0.532)$ & $(0.301)$ \\
\hline \multirow{2}{*}{$\Delta \pi_{t}$} & $1.865^{*}$ & $3.965 * * *$ & 1.316 & $3.079 * * *$ & $2.378 * * *$ & $3.836 * * *$ \\
\hline & $(0.958)$ & $(0.853)$ & (0.974) & $(0.829)$ & $(0.901)$ & $(0.813)$ \\
\hline \multirow{2}{*}{$\Delta i_{t}^{d}$} & 0.014 & $-0.070 * * *$ & 0.005 & $-0.075 * * *$ & 0.010 & $-0.068 * * *$ \\
\hline & $(0.026)$ & $(0.010)$ & $(0.021)$ & $(0.010)$ & $(0.021)$ & $(0.010)$ \\
\hline \multirow[t]{2}{*}{$\alpha_{0}$} & $9.232 * * *$ & $11.138 * * *$ & $3.654 * * *$ & $6.849 * * *$ & $3.637 * * *$ & $5.475 * * *$ \\
\hline & $(2.222)$ & (1.474) & (0.949) & (1.208) & $(1.052)$ & (1.265) \\
\hline \multirow{2}{*}{$\begin{array}{l}\text { Short run } \\
\text { asymmetry test }\end{array}$} & $12.91 * * *$ & 1.06 & 0.01 & 3.16 & $11.98 * * *$ & 2.27 \\
\hline & {$[0.000]$} & {$[0.302]$} & [0.905] & [0.076] & [0.001] & [0.132] \\
\hline \multirow{2}{*}{$\begin{array}{l}\text { Hausman test } \\
\chi_{k}^{2}[\text { Prob }]\end{array}$} & $16.10 *$ & $15.12 * *$ & 8.32 & $20.88 * * *$ & 6.24 & $22.58 * * *$ \\
\hline & {$[0.013]$} & {$[0.013]$} & {$[0.215]$} & {$[0.000]$} & [0.397] & {$[0.000]$} \\
\hline$N$ & 15 & 87 & 15 & 87 & 15 & 87 \\
\hline$N T$ & 3,030 & 17,574 & 3,030 & 17,574 & 3,030 & 17,574 \\
\hline
\end{tabular}

Note: The acronym E\&P denotes oil and gas exploration and production firms. * $\mathrm{p}<0.05 ; * * \mathrm{p}<0.01 ; * * * \mathrm{p}<0.001$. Nob is the number of observations. Values in ( ) and [ ] represent standard errors and probability values, respectively. The number of cross-sections and total panel observations are symbolized as $N$ and $N T$, respectively. The $\chi_{k}^{2}$ is the chi-squared statistic with $k$ degrees of freedom, which is determined by the number of estimated parameters in the long-run equation of the heterogeneous panel. The long run and short run asymmetry tests involve the Chi-square distributed Wald test. The test is used here to establish the equality or otherwise of the impact of positive and negative changes in the oil price on stock prices. Thus, the underlying null hypothesis for the test is that both asymmetric components of the oil price have an identical impact on the stock price, while the alternative hypothesis states otherwise (i.e., they do not have an identical impact). 
Table 7: Regression results without asymmetry for Retail and Marketing and Storage $\&$ Transportation firms of the Downstream Sector

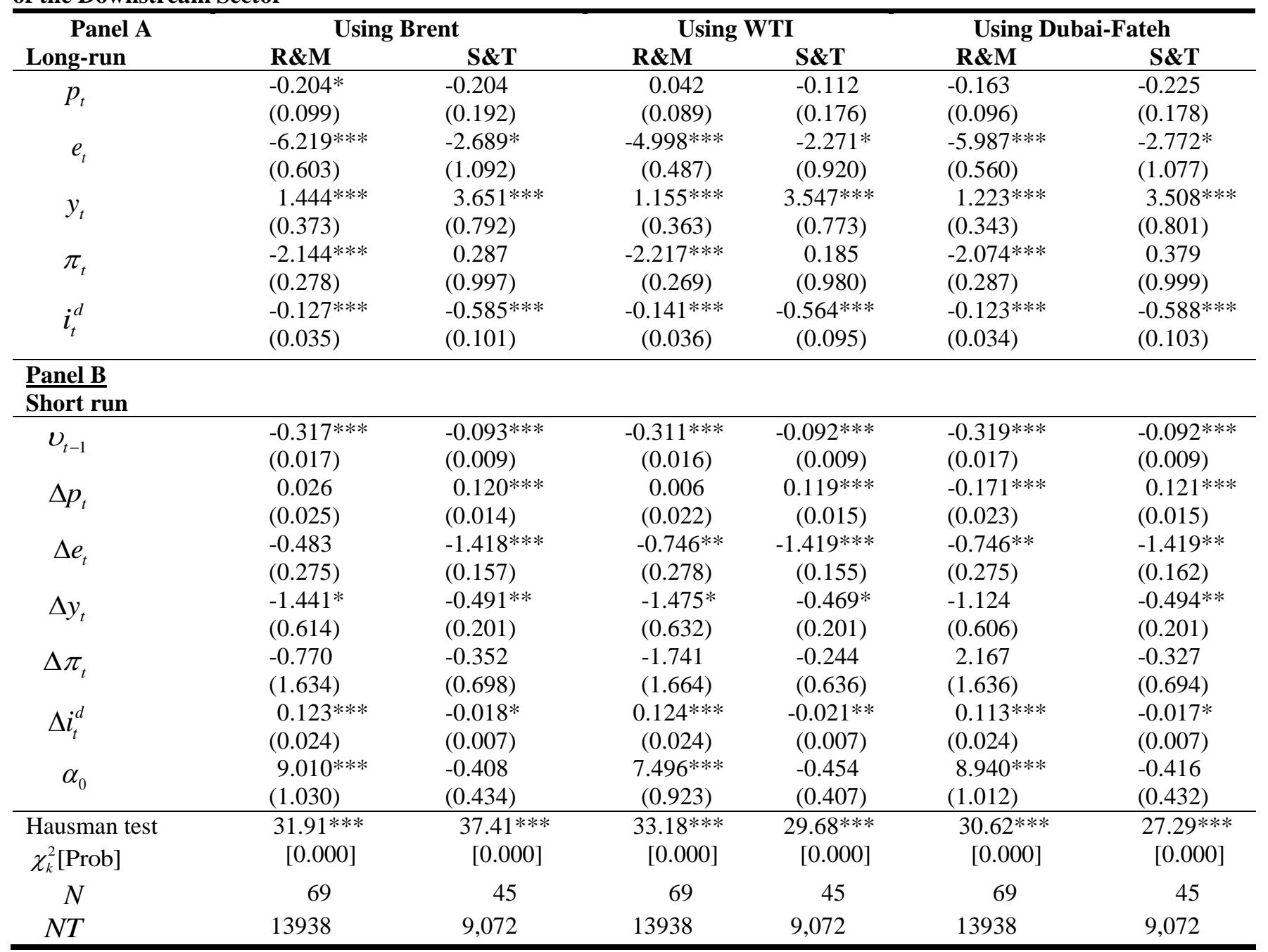

Note: The acronyms R\&M and S\&T denote Retail and Marketing and Storage \& Transportation firms, respectively. $* \mathrm{p}<0.05 ; * * \mathrm{p}<0.01 ; * * * \mathrm{p}<0.001$. Nob is the number of observations. Values in ( ) and [ ] represent standard errors and probability values, respectively. The number of cross-sections and total panel observations are symbolized as $N$ and $N T$, respectively. The $\chi_{k}^{2}$ is the chi-squared statistic with $k$ degrees of freedom, which is determined by the number of estimated parameters in the long-run equation of the heterogeneous panel. 
Table 8: Regression results with asymmetry for Retail and Marketing and Storage \& Transportation firms of the Downstream sector

\begin{tabular}{|c|c|c|c|c|c|c|}
\hline \multirow{2}{*}{$\begin{array}{l}\text { Panel A } \\
\text { Long-run }\end{array}$} & \multicolumn{2}{|c|}{ Using Brent } & \multicolumn{2}{|c|}{ Using WTI } & \multicolumn{2}{|c|}{ Using Dubai-Fateh } \\
\hline & $\mathbf{R} \& \mathbf{M}$ & S\&T & $\mathbf{R} \& \mathbf{M}$ & S\&T & $\mathbf{R} \& \mathbf{M}$ & S\&T \\
\hline$p_{t}^{+}$ & $\begin{array}{c}0.010 \\
(0.136)\end{array}$ & $\begin{array}{c}0.439 \\
(0.251)\end{array}$ & $\begin{array}{c}0.154^{*} \\
(0.072)\end{array}$ & $\begin{array}{c}0.416 \\
(0.254)\end{array}$ & $\begin{array}{l}-0.203^{*} \\
(0.090)\end{array}$ & $\begin{array}{c}0.017 \\
(0.263)\end{array}$ \\
\hline$p_{t}^{-}$ & $\begin{array}{l}-0.098 \\
(0.104)\end{array}$ & $\begin{array}{l}-0.076 \\
(0.157)\end{array}$ & $\begin{array}{c}0.122 \\
(0.081)\end{array}$ & $\begin{array}{c}0.025 \\
(0.166)\end{array}$ & $\begin{array}{l}-0.104 \\
(0.092)\end{array}$ & $\begin{array}{l}-0.147 \\
(0.176)\end{array}$ \\
\hline$e_{t}$ & $\begin{array}{l}-5.947 * * * \\
(0.588)\end{array}$ & $\begin{array}{l}-2.124^{*} \\
(0.849)\end{array}$ & $\begin{array}{c}-4.928 * * * \\
(0.484)\end{array}$ & $\begin{array}{l}-2.144^{*} \\
(0.857)\end{array}$ & $\begin{array}{l}-5.790 * * \\
(0.555)\end{array}$ & $\begin{array}{l}-2.640 * * \\
(1.011)\end{array}$ \\
\hline$y_{t}$ & $\begin{array}{l}1.713 \text { *** } \\
(0.328)\end{array}$ & $\begin{array}{l}2.689 * * * \\
(0.689)\end{array}$ & $\begin{array}{c}1.384 * * * \\
(0.422)\end{array}$ & $\begin{array}{c}4.276 * * * \\
(0.822)\end{array}$ & $\begin{array}{l}1.068 * * * \\
(0.385)\end{array}$ & $\begin{array}{l}3.931 * * * \\
(0.894)\end{array}$ \\
\hline$\pi_{t}$ & $\begin{array}{l}-4.555^{* * * *} \\
(1.302)\end{array}$ & $\begin{array}{l}-9.749 * * \\
(3.642)\end{array}$ & $\begin{array}{c}-3.103 * * \\
(1.069)\end{array}$ & $\begin{array}{l}-8.022 * \\
(3.446)\end{array}$ & $\begin{array}{l}-0.266 \\
(0.941)\end{array}$ & $\begin{array}{l}-3.013 \\
(3.063)\end{array}$ \\
\hline$i_{t}^{d}$ & $\begin{array}{l}-0.170 * * * \\
(0.040)\end{array}$ & $\begin{array}{l}-0.505 * * * \\
(0.076)\end{array}$ & $\begin{array}{c}-0.215^{* * *} * \\
(0.044)\end{array}$ & $\begin{array}{c}-0.470 * * * \\
(0.092)\end{array}$ & $\begin{array}{l}-0.193 * * * \\
(0.042)\end{array}$ & $\begin{array}{l}-0.533 * * * \\
(0.095)\end{array}$ \\
\hline $\begin{array}{l}\text { Long run } \\
\text { asymmetry test }\end{array}$ & $\begin{array}{c}3.81 \\
{[0.051]}\end{array}$ & $\begin{array}{c}9.56 * * \\
{[0.002]}\end{array}$ & $\begin{array}{c}0.40 \\
{[0.527]}\end{array}$ & $\begin{array}{c}5.75^{*} \\
{[0.017]}\end{array}$ & $\begin{array}{c}4.30 * \\
{[0.038]}\end{array}$ & $\begin{array}{c}1.18 \\
{[0.278]}\end{array}$ \\
\hline \multicolumn{7}{|l|}{ Panel B: Short run } \\
\hline $\bar{~} v_{t-1}$ & $\begin{array}{l}-0.325 * * * \\
(0.017)\end{array}$ & $\begin{array}{l}-0.034 * * * \\
(0.004)\end{array}$ & $\begin{array}{c}-0.317 \text { *** } \\
(0.016)\end{array}$ & $\begin{array}{c}-0.094 * * * \\
(0.009)\end{array}$ & $\begin{array}{l}-0.323 * * * \\
(0.017)\end{array}$ & $\begin{array}{l}-0.096 * * * \\
(0.009)\end{array}$ \\
\hline$\Delta p_{t}^{+}$ & $\begin{array}{l}0.435^{* * *} * \\
(0.057)\end{array}$ & $\begin{array}{c}0.071^{*} \\
(0.029)\end{array}$ & $\begin{array}{c}0.488 * * * \\
(0.064)\end{array}$ & $\begin{array}{c}0.072 * \\
(0.033)\end{array}$ & $\begin{array}{l}0.236 * * * \\
(0.047)\end{array}$ & $\begin{array}{l}0.104 * * \\
(0.033)\end{array}$ \\
\hline$\Delta p_{t}^{-}$ & $\begin{array}{l}-0.370 * * * \\
(0.044)\end{array}$ & $\begin{array}{l}0.140^{* * * *} \\
(0.028)\end{array}$ & $\begin{array}{c}-0.494 * * * \\
(0.051)\end{array}$ & $\begin{array}{c}0.136 * * * \\
(0.026)\end{array}$ & $\begin{array}{l}-0.484 * * * \\
(0.044)\end{array}$ & $\begin{array}{l}0.123 * * * \\
(0.028)\end{array}$ \\
\hline$\Delta e_{t}$ & $\begin{array}{l}-0.607 * \\
(0.268)\end{array}$ & $\begin{array}{l}-1.503 * * * \\
(0.152)\end{array}$ & $\begin{array}{l}-0.809 * * \\
(0.274)\end{array}$ & $\begin{array}{c}-1.400 * * * \\
(0.156)\end{array}$ & $\begin{array}{l}-0.923 * * * \\
(0.273)\end{array}$ & $\begin{array}{l}-1.416^{* * * *} \\
(0.161)\end{array}$ \\
\hline$\Delta y_{t}$ & $\begin{array}{l}-1.380^{*} \\
(0.572)\end{array}$ & $\begin{array}{l}-0.422^{*} \\
(0.204)\end{array}$ & $\begin{array}{c}-1.580 * * \\
(0.555)\end{array}$ & $\begin{array}{c}-0.641 * * * \\
(0.219)\end{array}$ & $\begin{array}{l}-0.896 \\
(0.554)\end{array}$ & $\begin{array}{l}-0.556^{* *} \\
(0.210)\end{array}$ \\
\hline$\Delta \pi_{t}$ & $\begin{array}{c}0.992 \\
(1.692)\end{array}$ & $\begin{array}{l}-0.265 \\
(0.704)\end{array}$ & $\begin{array}{c}0.662 \\
(1.671)\end{array}$ & $\begin{array}{l}-0.268 \\
(0.638)\end{array}$ & $\begin{array}{c}2.757 \\
(1.647)\end{array}$ & $\begin{array}{l}-0.280 \\
(0.680)\end{array}$ \\
\hline$\Delta i_{t}^{d}$ & $\begin{array}{l}0.124 * * * \\
(0.024)\end{array}$ & $\begin{array}{l}-0.030 * * * \\
(0.008)\end{array}$ & $\begin{array}{c}0.126 * * * \\
(0.024)\end{array}$ & $\begin{array}{c}-0.020 * * \\
(0.007)\end{array}$ & $\begin{array}{l}0.116^{* * * *} \\
(0.025)\end{array}$ & $\begin{array}{l}-0.017 * \\
(0.007)\end{array}$ \\
\hline$\alpha_{0}$ & $\begin{array}{l}10.691 \text { *** } \\
(2.356)\end{array}$ & $\begin{array}{l}1.678 * * * \\
(0.179)\end{array}$ & $\begin{array}{c}10.434 * * * \\
(2.079)\end{array}$ & $\begin{array}{c}1.859 \\
(0.968)\end{array}$ & $\begin{array}{l}6.950 * * * \\
(1.777)\end{array}$ & $\begin{array}{c}0.421 \\
(0.878)\end{array}$ \\
\hline $\begin{array}{l}\text { Short run } \\
\text { asymmetry test }\end{array}$ & $\begin{array}{l}86.76 * * * \\
{[0.000]}\end{array}$ & $\begin{array}{c}1.96 \\
{[0.161]}\end{array}$ & $\begin{array}{c}87.21 * * * \\
{[0.000]}\end{array}$ & $\begin{array}{c}1.60 \\
{[0.206]}\end{array}$ & $\begin{array}{l}88.42 \\
{[0.000]}\end{array}$ & $\begin{array}{c}0.13 \\
{[0.714]}\end{array}$ \\
\hline $\begin{array}{l}\text { Hausman test } \\
\chi_{k}^{2}[\text { Prob }]\end{array}$ & $\begin{array}{l}18.69^{* *} \\
{[0.005]}\end{array}$ & $\begin{array}{c}1.85 \\
{[0.9327]}\end{array}$ & $\begin{array}{c}19.49 * * \\
{[0.003]}\end{array}$ & $\begin{array}{c}16.92 * * \\
{[0.005]}\end{array}$ & $\begin{array}{c}19.92 * * * \\
{[0.0029]}\end{array}$ & $\begin{array}{c}84.62 \\
{[0.000]}\end{array}$ \\
\hline$N$ & 69 & 45 & 69 & 45 & 69 & 45 \\
\hline$N T$ & 13938 & 9,072 & 13938 & 9,072 & 13938 & 9,072 \\
\hline
\end{tabular}

Note: The acronyms R\&M and S\&T denote Retail and Marketing and Storage \& Transportation firms, respectively.

$* \mathrm{p}<0.05 ; * * \mathrm{p}<0.01 ; * * * \mathrm{p}<0.001$. Nob is the number of observations. Values in ( ) and [ ] represent standard errors and probability values, respectively. The number of cross-sections and total panel observations are symbolized as $N$ and $N T$, respectively. The $\chi_{k}^{2}$ is the chi-squared statistic with $k$ degrees of freedom, which is determined by the number of estimated parameters in the long-run equation of the heterogeneous panel. The long run and short run asymmetry tests involve the Chi-square distributed Wald test. The test is used here to establish the equality or otherwise of the impact of positive and negative changes in the oil price on stock prices. Thus, the underlying null hypothesis for the test is that both asymmetric components of the oil price have an identical impact on the stock price, while the alternative hypothesis states otherwise (i.e., they do not have an identical impact). 
Table 9: Regression results for Pre-Global Financial Crisis

Table 9a: Regression results (without asymmetry) for Upstream and Downstream sectors

\begin{tabular}{|c|c|c|c|c|c|c|}
\hline \multirow{2}{*}{$\frac{\text { Panel A }}{\text { Long-run }}$} & \multicolumn{2}{|c|}{ Using Brent } & \multicolumn{2}{|c|}{ Using WTI } & \multicolumn{2}{|c|}{ Using Dubai-Fateh } \\
\hline & Upstream & Downstream & Upstream & Downstream & Upstream & Downstream \\
\hline \multirow{2}{*}{$p_{t}$} & 0.346 & -0.230 & 0.330 & -0.143 & 0.171 & $-0.531 * *$ \\
\hline & $(0.201)$ & $(0.123)$ & $(0.171)$ & $(0.120)$ & $(0.285)$ & $(0.161)$ \\
\hline \multirow{2}{*}{$e_{t}$} & -2.227 & $-5.657 * *$ & -1.934 & $-5.797 * * *$ & $-2.886^{*}$ & $-5.203 * * *$ \\
\hline & (1.428) & $(0.733)$ & (1.454) & $(0.682)$ & $(1.153)$ & $(0.903)$ \\
\hline \multirow{2}{*}{$y_{t}$} & $5.535^{* *}$ & $4.214 * * *$ & $6.025 * * *$ & $3.506^{* *}$ & $6.238^{*}$ & $6.688^{*}$ \\
\hline & $(1.865)$ & (1.557) & (1.757) & $(1.361)$ & $(2.611)$ & (2.368) \\
\hline \multirow{2}{*}{$\pi_{t}$} & -0.411 & -0.788 & -0.124 & -1.121 & -0.501 & 0.014 \\
\hline & $(2.082)$ & $(0.745)$ & $(2.073)$ & $(0.716)$ & (1.693) & $(0.728)$ \\
\hline \multirow{2}{*}{$i_{t}^{d}$} & $-0.369 *$ & $-0.409 * * *$ & $-0.371 *$ & $-0.399 * * *$ & $-0.377^{*}$ & $-0.422 * *$ \\
\hline & $(0.164)$ & $(0.067)$ & $(0.161)$ & $(0.062)$ & $(0.167)$ & $(0.097)$ \\
\hline \multirow{2}{*}{\multicolumn{7}{|c|}{$\frac{\text { Panel B }}{\text { Short run }}$}} \\
\hline & & & & & & \\
\hline \multirow{2}{*}{$v_{t-1}$} & $-0.200 * * *$ & $-0.402 * * *$ & $-0.205 * * *$ & $-0.407 * * *$ & $-0.192 * * *$ & $-0.398 * * *$ \\
\hline & $(0.011)$ & $(0.023)$ & $(0.011)$ & $(0.023)$ & $(0.011)$ & $(0.023)$ \\
\hline \multirow{2}{*}{$\Delta p_{t}$} & $0.045^{*}$ & $0.278 * * *$ & $0.070 *$ & $0.294 * * *$ & 0.036 & $0.148 * * *$ \\
\hline & $(0.025)$ & $(0.036)$ & $(0.029)$ & $(0.037)$ & $(0.030)$ & $(0.031)$ \\
\hline \multirow{2}{*}{$\Delta e_{t}$} & $-0.856 * * *$ & -0.179 & $-0.836 * * *$ & -0.057 & $-0.847 * * *$ & -0.145 \\
\hline & $(0.207)$ & $(0.205)$ & $(0.210)$ & $(0.209)$ & $(0.201)$ & $(0.207)$ \\
\hline \multirow{2}{*}{$\Delta y_{t}$} & -0.718 & $-3.466 * * *$ & -0.829 & $-3.446 * * *$ & -0.753 & $-3.026 * * *$ \\
\hline & $(0.448)$ & (0.804) & $(0.449)$ & $(0.773)$ & $(0.440)$ & $(0.756)$ \\
\hline \multirow{2}{*}{$\Delta \pi_{t}$} & $4.498 * * *$ & -2.249 & $4.197 * * *$ & -2.358 & $5.218^{* * *}$ & 0.471 \\
\hline & $(0.802)$ & (1.489) & $(0.817)$ & $(1.512)$ & $(0.767)$ & $(1.376)$ \\
\hline \multirow[t]{2}{*}{$\Delta i_{t}^{d}$} & -0.000 & $0.111 * * *$ & 0.001 & $0.112 * * *$ & -0.006 & $0.096 * * *$ \\
\hline & $(0.015)$ & $(0.025)$ & $(0.015)$ & $(0.025)$ & $(0.014)$ & $(0.025)$ \\
\hline \multirow{2}{*}{$\alpha_{0}$} & -4.048 & $15.737 * * *$ & $-4.164 *$ & $16.545 * * *$ & $-6.022 * *$ & $12.089 * *$ \\
\hline & $(2.189)$ & $(4.203)$ & $(2.062)$ & $(4.138)$ & $(2.183)$ & (3.818) \\
\hline Hausman test & $46.33 * * *$ & $40.88 * * *$ & 40.71 *** & $33.33 * * *$ & $67.81 * * *$ & $26.10 * * *$ \\
\hline \multicolumn{7}{|l|}{$\chi_{k}^{2}[$ Prob $]$} \\
\hline$N$ & 102 & 114 & 102 & 114 & 102 & 114 \\
\hline$N T$ & 8,976 & 10,032 & 8,976 & 10,032 & 8,976 & 10,032 \\
\hline
\end{tabular}

Note: $* \mathrm{p}<0.05 ; * * \mathrm{p}<0.01 ; * * * \mathrm{p}<0.001$. Nob is the number of observations. Values in ( ) and [ ] represent standard errors and probability values, respectively. The number of cross-sections and total panel observations are symbolized as $N$ and $N T$, respectively. The $\chi_{k}^{2}$ is the chi-squared statistic with $k$ degrees of freedom, which is determined by the number of estimated parameters in the long-run equation of the heterogeneous panel. 
Table 9b: Regression results (with asymmetry) for Upstream and Downstream sectors

\begin{tabular}{|c|c|c|c|c|c|c|}
\hline \multirow{2}{*}{$\frac{\text { Panel A }}{\text { Long-run }}$} & \multicolumn{2}{|c|}{ Using Brent } & \multicolumn{2}{|c|}{ Using WTI } & \multicolumn{2}{|c|}{ Using Dubai-Fateh } \\
\hline & Upstream & Downstream & Upstream & Downstream & Upstream & Downstream \\
\hline$p_{t}^{+}$ & $1.060 * * *$ & $\begin{array}{l}-0.040 \\
(0159)\end{array}$ & $1.051 * * *$ & $\begin{array}{l}-0.051 \\
(0175)\end{array}$ & $1.009 * * *$ & $\begin{array}{l}-0.129 \\
(0153)\end{array}$ \\
\hline$p_{t}^{-}$ & $\begin{array}{c}-1.335 * * * * \\
(0.223)\end{array}$ & $\begin{array}{l}-0.245^{*} \\
(0.115)\end{array}$ & $\begin{array}{l}-0.305 \\
(0.172)\end{array}$ & $\begin{array}{l}-0.104 \\
(0.159)\end{array}$ & $\begin{array}{r}-0.641 * * \\
(0.242)\end{array}$ & $\begin{array}{l}-0.420^{* * *} \\
(0.153)\end{array}$ \\
\hline$e_{t}$ & $\begin{array}{c}0.448 \\
(0.780)\end{array}$ & $\begin{array}{l}-5.565 * * * \\
(0.666)\end{array}$ & $\begin{array}{r}1.098 \\
(1.562)\end{array}$ & $\begin{array}{l}-6.149 * * * \\
(0.912)\end{array}$ & $\begin{array}{r}0.360 \\
(1.074)\end{array}$ & $\begin{array}{l}-5.376 * * * \\
(0.773)\end{array}$ \\
\hline$y_{t}$ & $\begin{array}{c}14.412 * * * \\
(1.819)\end{array}$ & $\begin{array}{c}2.834^{*} \\
(1.390)\end{array}$ & $\begin{array}{r}9.007 * * * \\
(1.596)\end{array}$ & $\begin{array}{l}1.646 \\
(1.862)\end{array}$ & $\begin{array}{r}12.519 * * * \\
(1.980)\end{array}$ & $\begin{array}{l}4.031 * * \\
(1.793)\end{array}$ \\
\hline$\pi_{t}$ & $\begin{array}{c}-38.510 * * * \\
(4.751)\end{array}$ & $\begin{array}{l}-3.664 \\
(2.546)\end{array}$ & $\begin{array}{r}-18.595 * * * \\
(4.747)\end{array}$ & $\begin{array}{l}-1.434 \\
(3.623)\end{array}$ & $\begin{array}{r}-22.977 * * * \\
(4.326)\end{array}$ & $\begin{array}{l}-3.900 \\
(2.510)\end{array}$ \\
\hline$i_{t}^{d}$ & $\begin{array}{l}0.291 * * * \\
(0.091)\end{array}$ & $\begin{array}{l}-0.264 * * * \\
(0.050)\end{array}$ & $\begin{array}{l}-0.030 \\
(0.129)\end{array}$ & $\begin{array}{l}-0.276^{* * * *} \\
(0.053)\end{array}$ & $\begin{array}{r}0.005 \\
(0.103)\end{array}$ & $\begin{array}{l}-0.233 * * * \\
(0.054)\end{array}$ \\
\hline $\begin{array}{l}\text { Long run } \\
\text { asymmetry test }\end{array}$ & $\begin{array}{l}74.67 * * * \\
{[0.000]}\end{array}$ & $\begin{array}{c}3.55 \\
{[0.060]}\end{array}$ & $\begin{array}{r}21.81 * * * \\
{[0.000]}\end{array}$ & $\begin{array}{c}1.15 \\
{[0.282]}\end{array}$ & $\begin{array}{r}30.38 * * * \\
{[0.000]}\end{array}$ & $\begin{array}{c}5.65^{*} \\
{[0.018]}\end{array}$ \\
\hline $\begin{array}{l}\text { Panel B: } \\
\text { Short run }\end{array}$ & & & & & & \\
\hline$v_{t-1}$ & $\begin{array}{c}-0.077 * * * \\
(0.005)\end{array}$ & $\begin{array}{l}-0.413 * * * \\
(0.023)\end{array}$ & $\begin{array}{r}-0.219 * * * \\
(0.013)\end{array}$ & $\begin{array}{l}-0.416^{* * * *} \\
(0.023)\end{array}$ & $\begin{array}{r}-0.199 * * * \\
(0.012)\end{array}$ & $\begin{array}{l}-0.405 * * * \\
(0.023)\end{array}$ \\
\hline$\Delta p_{t}^{+}$ & $\begin{array}{l}0.131^{* *} \\
(0.046)\end{array}$ & $\begin{array}{l}0.486 * * * \\
(0.069)\end{array}$ & $\begin{array}{l}-0.057 \\
(0.055)\end{array}$ & $\begin{array}{l}0.312 * * * \\
(0.066)\end{array}$ & $\begin{array}{r}0.076 \\
(0.053)\end{array}$ & $\begin{array}{l}0.397 * * * \\
(0.060)\end{array}$ \\
\hline$\Delta p_{t}^{-}$ & $\begin{array}{l}-0.071 \\
(0.050)\end{array}$ & $\begin{array}{c}0.011 \\
(0.047)\end{array}$ & $\begin{array}{l}0.114^{*} \\
(0.057)\end{array}$ & $\begin{array}{l}0.218 * * * \\
(0.059)\end{array}$ & $\begin{array}{c}-0.062 \\
(0.056)\end{array}$ & $\begin{array}{l}-0.116^{*} \\
(0.052)\end{array}$ \\
\hline$\Delta e_{t}$ & $\begin{array}{c}-0.993 * * * \\
(0.201)\end{array}$ & $\begin{array}{l}-0.038 \\
(0.213)\end{array}$ & $\begin{array}{r}-0.906 * * * \\
(0.216)\end{array}$ & $\begin{array}{l}-0.038 \\
(0.211)\end{array}$ & $\begin{array}{r}-0.842 * * * \\
(0.204)\end{array}$ & $\begin{array}{l}-0.109 \\
(0.206)\end{array}$ \\
\hline$\Delta y_{t}$ & $\begin{array}{l}-0.785 \\
(0.423)\end{array}$ & $\begin{array}{l}-3.654 * * * \\
(0.772)\end{array}$ & $\begin{array}{r}-1.135^{*} \\
(0.448)\end{array}$ & $\begin{array}{l}-3.828 * * * \\
(0.752)\end{array}$ & $\begin{array}{r}-1.202 * * \\
(0.437)\end{array}$ & $\begin{array}{l}-3.602 * * * \\
(0.732)\end{array}$ \\
\hline$\Delta \pi_{t}$ & $\begin{array}{l}6.099 * * * \\
(0.878)\end{array}$ & $\begin{array}{l}-0.559 \\
(1.380)\end{array}$ & $\begin{array}{r}4.933 * * * \\
(0.833)\end{array}$ & $\begin{array}{l}-1.438 \\
(1.417)\end{array}$ & $\begin{array}{r}5.894 * * * \\
(0.769)\end{array}$ & $\begin{array}{c}1.302 \\
(1.311)\end{array}$ \\
\hline$\Delta i_{t}^{d}$ & $\begin{array}{c}-0.058 * * * \\
(0.012)\end{array}$ & $\begin{array}{l}0.067 * * \\
(0.025)\end{array}$ & $\begin{array}{l}-0.022 \\
(0.013)\end{array}$ & $\begin{array}{l}0.086^{* * * *} \\
(0.025)\end{array}$ & $\begin{array}{r}-0.035 * * \\
(0.013)\end{array}$ & $\begin{array}{l}0.056^{*} \\
(0.025)\end{array}$ \\
\hline$\alpha_{0}$ & $\begin{array}{l}9.968 * * * \\
(0.627)\end{array}$ & $\begin{array}{l}25.710 * * * \\
(6.994)\end{array}$ & $\begin{array}{r}3.845 \\
(3.818)\end{array}$ & $\begin{array}{l}24.135 * * * \\
(6.289)\end{array}$ & $\begin{array}{r}2.402 \\
(3.522)\end{array}$ & $\begin{array}{l}21.725^{* * * *} \\
(5.918)\end{array}$ \\
\hline $\begin{array}{l}\text { Short run } \\
\text { asymmetry test }\end{array}$ & $\begin{array}{c}5.91 * \\
{[0.015]}\end{array}$ & $\begin{array}{l}26.75 * * * \\
{[0.000]}\end{array}$ & $\begin{array}{c}3.53 \\
{[0.060]}\end{array}$ & $\begin{array}{c}0.88 \\
{[0.349]}\end{array}$ & $\begin{array}{c}2.40 \\
{[0.122]}\end{array}$ & $\begin{array}{l}30.30 * * * \\
{[0.000]}\end{array}$ \\
\hline $\begin{array}{l}\text { Hausman test } \\
\chi_{k}^{2}[\text { Prob }]\end{array}$ & $\begin{array}{c}10.36 \\
{[0.1103]}\end{array}$ & $\begin{array}{c}22.19 * * * \\
{[0.000]}\end{array}$ & $\begin{array}{c}18.54 * * * \\
{[0.000]}\end{array}$ & $\begin{array}{c}55.37 * * * \\
{[0.000]}\end{array}$ & $\begin{array}{l}14.82 * \\
{[0.022]}\end{array}$ & $\begin{array}{c}37.80 * * * \\
{[0.000]}\end{array}$ \\
\hline$N$ & 102 & 114 & 102 & 114 & 102 & 114 \\
\hline$N T$ & 8,976 & 10,032 & 8,976 & 10,032 & 8,976 & 10,032 \\
\hline
\end{tabular}

Note: $* \mathrm{p}<0.05 ; * * \mathrm{p}<0.01 ; * * * \mathrm{p}<0.001$. Nob is the number of observations. Values in ( ) and [ ] represent standard errors and probability values respectively. The number of cross-sections and total panel observations are respectively symbolized as $N$ and $N T$. The $\chi_{k}^{2}$ is the chi-squared statistic with $k$ degrees of freedom which is determined by the number of estimated parameters in the long-run equation of the heterogeneous panel. The long run and short run asymmetry tests involve the Chi-square distributed Wald test. The test is used here to establish the equality or otherwise of the impact of positive and negative changes in oil price on stock prices. Thus, the underlying null hypothesis for the test is that both asymmetric components of oil price have an identical impact on stock price, while the alternative hypothesis states otherwise (i.e., they do not have an identical impact). 
Table 10: Regression results for Post-Global Financial Crisis

Table 10a: Regression results (without asymmetry) for Upstream and Downstream sectors

\begin{tabular}{|c|c|c|c|c|c|c|}
\hline \multirow{2}{*}{$\frac{\text { Panel A }}{\text { Long-run }}$} & \multicolumn{2}{|c|}{ Using Brent } & \multicolumn{2}{|c|}{ Using WTI } & \multicolumn{2}{|c|}{ Using Dubai-Fateh } \\
\hline & Upstream & Downstream & Upstream & Downstream & Upstream & Downstream \\
\hline \multirow{2}{*}{$p_{t}$} & $0.990 * * *$ & $0.404 * * *$ & $0.743 * * *$ & $0.362 * * *$ & $0.826 * * *$ & $0.483 * * *$ \\
\hline & $(0.121)$ & $(0.070)$ & $(0.099)$ & $(0.056)$ & $(0.111)$ & $(0.067)$ \\
\hline \multirow{2}{*}{$e_{t}$} & 0.853 & 0.285 & -1.185 & -0.281 & 0.003 & $0.780 * *$ \\
\hline & $(0.677)$ & $(0.293)$ & $(0.681)$ & $(0.276)$ & $(0.666)$ & $(0.273)$ \\
\hline \multirow{2}{*}{$y_{t}$} & $2.056^{* *}$ & $2.078 * * *$ & $1.437 * *$ & $1.985 * * *$ & $2.277 * * *$ & $2.141 * * *$ \\
\hline & $(0.550)$ & $(0.341)$ & $(0.575)$ & $(0.343)$ & $(0.545)$ & $(0.331)$ \\
\hline \multirow{2}{*}{$\pi_{t}$} & $-11.758 * * *$ & $-4.895 * * *$ & $-9.774 * * *$ & $-4.339 * * *$ & $-11.575 * * *$ & $-5.023 * * *$ \\
\hline & $(1.238)$ & $(0.932)$ & $(1.151)$ & $(0.903)$ & (1.213) & $(0.902)$ \\
\hline$i_{t}^{d}$ & $\begin{array}{r}-0.278 * * * \\
(0.053)\end{array}$ & $\begin{array}{l}-0.378 * * * \\
(0.043)\end{array}$ & $\begin{array}{c}-0.188 * * * \\
(0.056)\end{array}$ & $\begin{array}{l}-0.368 * * * \\
(0.043)\end{array}$ & $\begin{array}{r}-0.260 * * * \\
(0.054)\end{array}$ & $\begin{array}{l}-0.381 * * * \\
(0.042)\end{array}$ \\
\hline \multicolumn{7}{|l|}{ Panel B } \\
\hline \multicolumn{7}{|l|}{ Short run } \\
\hline \multirow[t]{2}{*}{$v_{t-1}$} & $-0.240 * * *$ & $-0.296 * * *$ & $-0.243 * * *$ & $-0.292 * * *$ & $-0.241 * * *$ & $-0.299 * * *$ \\
\hline & $(0.011)$ & $(0.013)$ & $(0.011)$ & $(0.013)$ & $(0.011)$ & (0.013) \\
\hline \multirow{2}{*}{$\Delta p_{t}$} & $0.305^{* * *}$ & $-0.247 * * *$ & $0.237 * * *$ & $-0.143 * * *$ & $0.304 * * *$ & $-0.279 * * *$ \\
\hline & $(0.045)$ & $(0.045)$ & $(0.038)$ & $(0.035)$ & $(0.042)$ & $(0.049)$ \\
\hline \multirow{2}{*}{$\Delta e_{t}$} & $-1.944 * * *$ & $-1.352 * * *$ & $-1.921 * * *$ & $-1.025 * * *$ & $-1.955 * * *$ & $-1.517 * * *$ \\
\hline & $(0.199)$ & $(0.258)$ & $(0.194)$ & $(0.288)$ & $(0.194)$ & $(0.259)$ \\
\hline \multirow{2}{*}{$\Delta y_{t}$} & 0.042 & -0.728 & 0.275 & -0.843 & 0.130 & -0.742 \\
\hline & $(0.310)$ & $(0.446)$ & $(0.325)$ & $(0.435)$ & $(0.310)$ & $(0.446)$ \\
\hline \multirow{2}{*}{$\Delta \pi_{t}$} & -1.185 & -0.777 & 1.995 & $-2.257 * *$ & -0.791 & -0.463 \\
\hline & $(1.173)$ & $(0.693)$ & (1.048) & $(0.716)$ & $(1.142)$ & $(0.755)$ \\
\hline \multirow{2}{*}{$\Delta i_{t}^{d}$} & $-0.016^{*}$ & $0.122 * * *$ & $-0.035^{* * *}$ & $0.122 * * *$ & -0.010 & $0.117 * * *$ \\
\hline & $(0.009)$ & $(0.017)$ & $(0.010)$ & $(0.017)$ & $(0.009)$ & $(0.017)$ \\
\hline \multirow{2}{*}{$\alpha_{0}$} & $10.798 * * *$ & $6.597 * * *$ & $11.034 * * *$ & $6.239 * * *$ & $11.201 * * *$ & $6.042 * * *$ \\
\hline & $(1.539)$ & $(1.371)$ & $(1.588)$ & $(1.373)$ & $(1.541)$ & $(1.391)$ \\
\hline Hausman test & $39.42 * * *$ & $66.04 * * *$ & $39.35 * * *$ & $45.53 * * *$ & $37.62 * * *$ & $54.50 * * *$ \\
\hline \multicolumn{7}{|l|}{$\chi_{k}^{2}[$ Prob $]$} \\
\hline$N$ & 102 & 114 & 102 & 114 & 102 & 114 \\
\hline$N T$ & 11,628 & 12,996 & 11,628 & 12,996 & 20,604 & 12,996 \\
\hline
\end{tabular}

Note: $* p<0.05 ; * * p<0.01 ; * * * p<0.001$. Nob is the number of observations. Values in () and [ ] represent standard errors and probability values, respectively. The number of cross-sections and total panel observations are symbolized as $N$ and $N T$, respectively. The $\chi_{k}^{2}$ is the chi-squared statistic with $k$ degrees of freedom, which is determined by the number of estimated parameters in the long-run equation of the heterogeneous panel. 
Table 10b: Regression results (with asymmetry) for Upstream and Downstream sectors

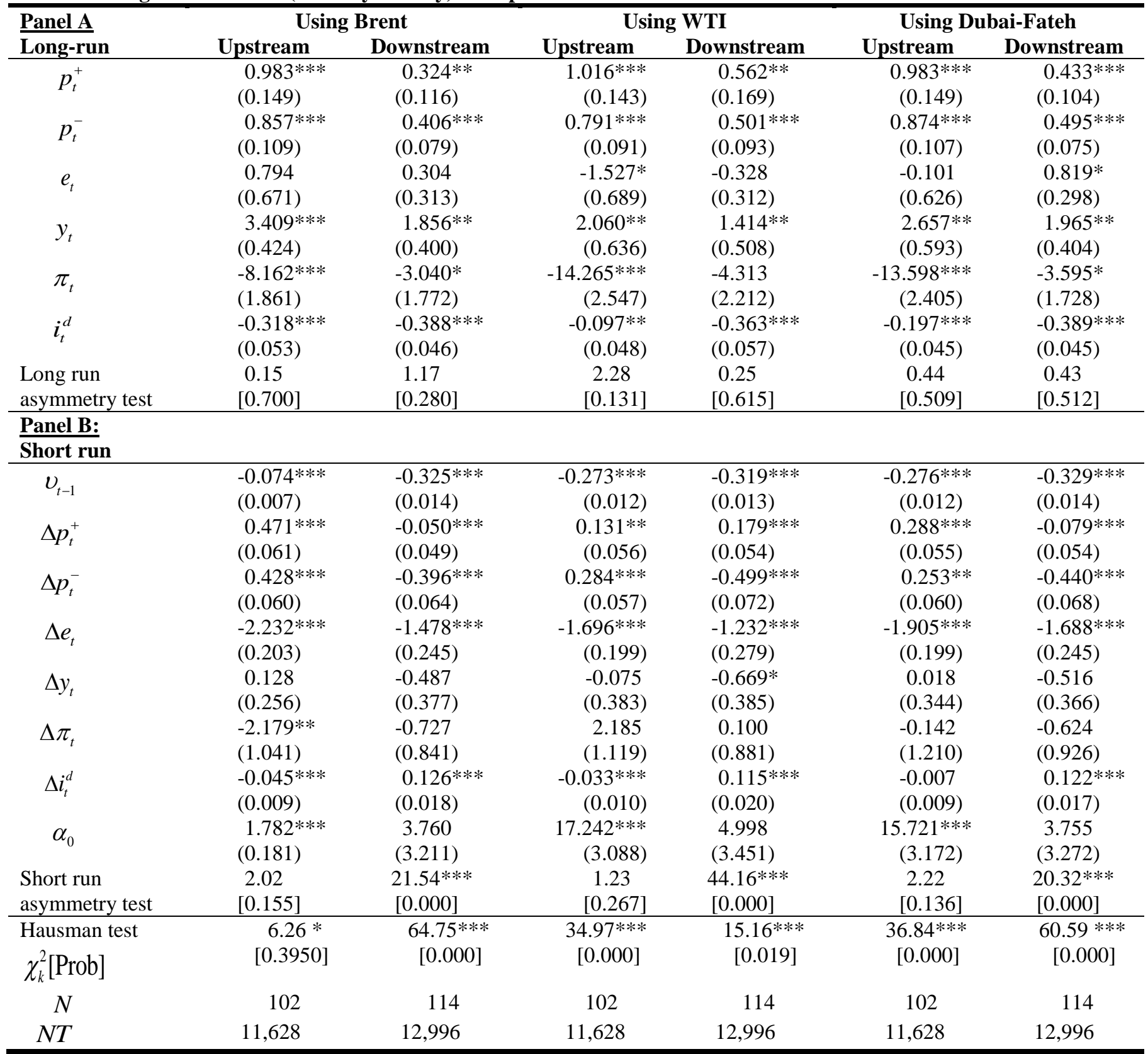

Note: $* \mathrm{p}<0.05 ; * * \mathrm{p}<0.01 ; * * * \mathrm{p}<0.001$. Nob is the number of observations. Values in ( ) and [ ] represent standard errors and probability values, respectively. The number of cross-sections and total panel observations are symbolized as $N$ and $N T$, respectively. The $\chi_{k}^{2}$ is the chi-squared statistic with $k$ degrees of freedom, which is determined by the number of estimated parameters in the long-run equation of the heterogeneous panel. The long run and short run asymmetry tests involve the Chi-square distributed Wald test. The test is used here to establish the equality or otherwise of the impact of positive and negative changes in the oil price on stock prices. Thus, the underlying null hypothesis for the test is that both asymmetric components of the oil price have an identical impact on the stock price, while the alternative hypothesis states otherwise (i.e., they do not have an identical impact). 